\title{
The Circular Carbon Economy Index 2021 - Methodology
}

\section{Mari Luomi, Fatih Yilmaz, Thamir Alshehri}




\section{Acknowledgments}

The authors are extremely grateful to all experts, stakeholders and data providers who contributed in various ways to this project. This included sharing data, clarifying dataset and indicator methodologies, discussing concepts and metrics, providing insights from different country contexts, exchanging views on the best ways to measure the various dimensions of the index, validating the results, developing the index web portal, and helping with the publications, events and outreach related to the index.

These individuals include Dr. Anvita Arora, Dr. Fahad Alturki, Dr. Frank Felder, Fahad Alajlan, Dr. Gasem Fallatah and his team, Ahmed Al-Zahrani, Amar Amarnath, Pavithra Kumar Shetty, and Alaa Alarfaj from KAPSARC's Energy Information Management program, colleagues at KAPSARC's Climate and Environment, Energy Transitions and Electric Power, Markets and Industrial Development, Library, Events and Communications teams, and speakers and participants at the KAPSARC stakeholder engagement workshop for the CCE Index (June 6, 2021).

We also met and exchanged emails with dozens of other experts and data providers. We are particularly thankful to the experts and data providers at BloombergNEF, EY, the Global CCS Institute and the World Intellectual Property Organization for sharing additional data and advising on imputations.

We wish to extend a special thanks to the members of the CCE Index International Technical Advisory Committee members:

Dr. Christopher Consoli, Global Carbon Capture and Storage Institute

Prof. Jorge Gascon, King Abdullah University of Science and Technology

Yoshikazu Kobayashi, The Institute of Energy Economics, Japan

Dr. Coby van der Linde, Clingendael International Energy Programme

Dr. Anupama Sen, Oxford Institute for Energy Studies

\section{About KAPSARC}

The King Abdullah Petroleum Studies and Research Center (KAPSARC) is a non-profit global institution dedicated to independent research into energy economics, policy, technology and the environment across all types of energy. KAPSARC's mandate is to advance the understanding of energy challenges and opportunities facing the world today and tomorrow, through unbiased, independent, and high-caliber research for the benefit of society. KAPSARC is located in Riyadh, Saudi Arabia.

This publication is also available in Arabic.

\section{Legal Notice}

(C) Copyright 2021 King Abdullah Petroleum Studies and Research Center ("KAPSARC").

This Document (and any information, data or materials contained therein) (the "Document") shall not be used without the proper attribution to KAPSARC. The Document shall not be reproduced, in whole or in part, without the written permission of KAPSARC. KAPSARC makes no warranty, representation or undertaking whether expressed or implied, nor does it assume any legal liability, whether direct or indirect, or responsibility for the accuracy, completeness, or usefulness of any information that is contained in the Document. Nothing in the Document constitutes or shall be implied to constitute advice, recommendation or option. The views and opinions expressed in this publication are those of the authors and do not necessarily reflect the official views or position of KAPSARC. 


\section{Summary}

$\mathbf{T}$ The Circular Carbon Economy Index (CCE Index) aims to measure countries' progress in and potential for achieving circular carbon economies (CCEs). The CCE Index is based on two sub-indices: one for measuring countries' current performance in the various dimensions of the CCE and the other for gauging how countries are positioned to make progress toward the CCE, based on key enabling factors. The CCE Index also allows for additional comparisons among top oil-producing countries through a separate set of add-on indicators that estimate how these countries' industrial performance and business environments are aligning with the CCE.

The CCE Index scores countries on a scale of $0-100$. It also provides a rank for each country to facilitate comparisons across countries. The 2021 edition of the CCE Index comprises a total of 47 indicators. Eight indicators measure performance, and 29 measure enabling factors. In total, therefore, the CCE Index consists of three aggregate scores: the CCE Performance score, the CCE Enablers score, and the total CCE Index score. Ten oil producer-specific indicators, referred to as the Oil Producers Lens, are applied to major oil-producing countries to form three additional scores: the Oil Producers Lens Performance score, the Oil Producers Lens Enablers score, and the Oil Producers Lens total score.
This paper presents the framework and methodology for the 2021 CCE Index, divided into the following sections: the conceptual framework; data selection; data preparation and processing; validation; stakeholder engagement; and future editions. Detailed information about the 2021 edition is included in tables within the sections and appendices.

An analysis and interpretation of the 2021 CCE Index results is presented in a separate KAPSARC Discussion Paper. The index results are also available on the CCE Index web portal: https:// cceindex.kapsarc.org. 


\section{Introduction}

his paper presents the framework and methodology of the CCE Index and its first edition. An analysis and interpretation of the 2021 CCE Index results is presented in the KAPSARC Discussion Paper "CCE Index 2021 - Results" (Luomi, Yilmaz, and Alshehri 2021a). The results are also available in an interactive format on the CCE Index web portal: https://cceindex.kapsarc.org.

\section{Objective}

The Circular Carbon Economy Index (CCE Index) aims to measure countries' progress in and potential for achieving circular carbon economies
(CCEs) (Figure 1). The CCE Index is based on two sub-indices: one for measuring countries' current performance in the various dimensions of the CCE and the other for gauging how countries are positioned to make progress toward the CCE, based on key enabling factors. The CCE Index also allows for additional comparisons among top oil-producing countries through a separate set of add-on indicators that estimate how these countries' industrial performance and business environments are aligning with the CCE. 
Figure 1. The circular carbon economy.

\section{REDUCE}

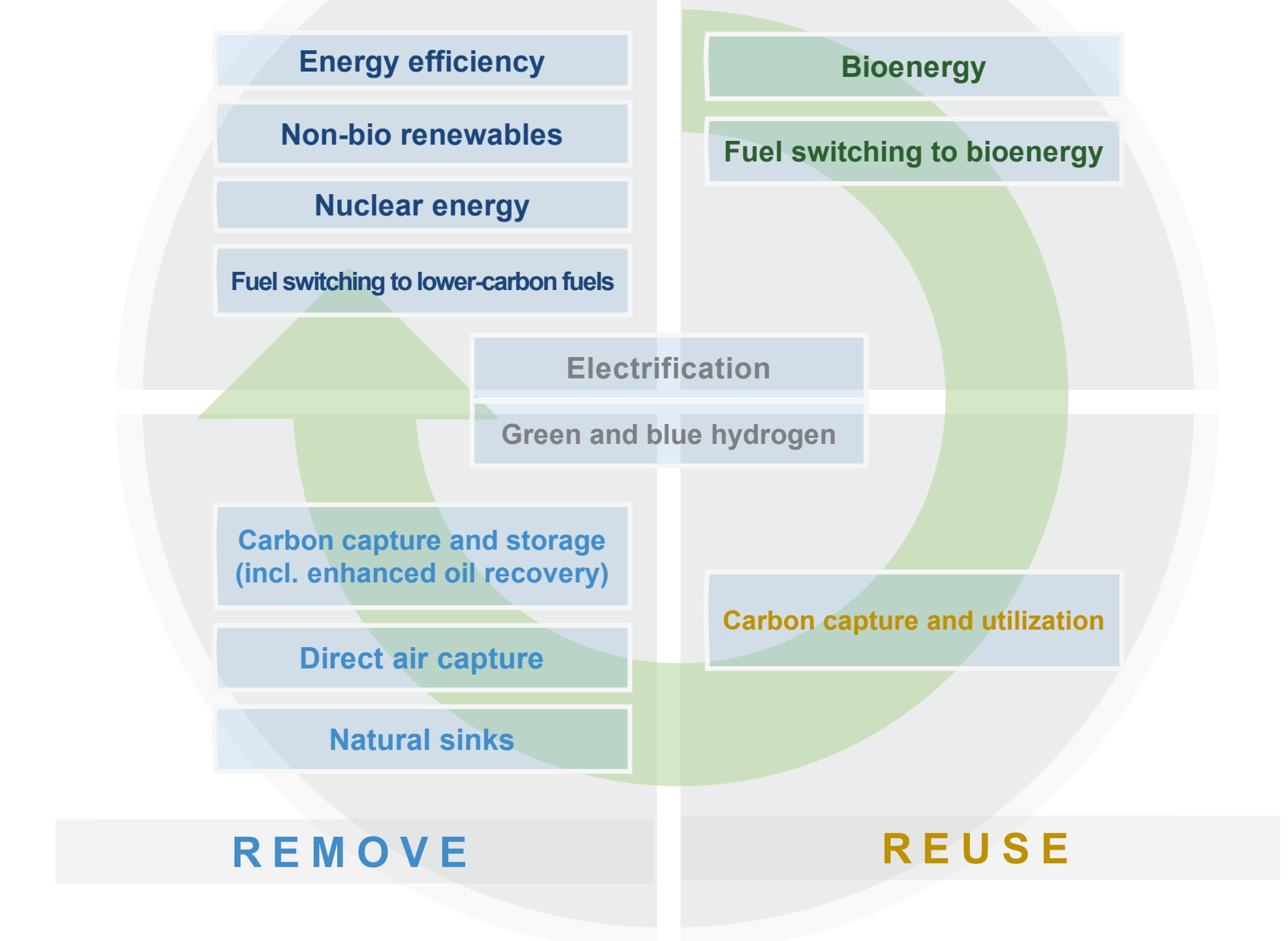

\section{RECYCLE}

Source: Authors, based on KAPSARC (2020); G20 Energy Ministers (2020). 
The KAPSARC paper "The Circular Carbon Economy Index - Methodological Approach and Conceptual Framework" (Luomi et al. 2021) explains in detail the rationale and need for a composite indicator (index) to measure and compare countries on their CCE performance and potential. Box 1 shows a list of intended uses for the CCE Index.

Box 1. Examples of intended uses for the CCE Index.

\section{Supporting global policy discussions:}

- Clarifying the CCE concept by identifying key activities/elements, and enablers;

- Helping make the CCE concept measurable at the country level;

- Providing a tool for tracking CCE quantitatively across countries;

- Highlighting areas of progress, gaps and potential on the road to carbon circularity and net-zero emissions;

- Illustrating ways for fossil fuel use to be made consistent with a net-zero emissions world (through

- technologies, including carbon capture, utilization and storage, and blue hydrogen);

- Creating opportunities for sharing experiences and policy learning across countries.

\section{Supporting domestic policy discussions:}

- Providing broad metrics for measuring performance and enablers at the economy-wide level;

- Creating a 'common language' for policy discussions among all stakeholders;

- Enabling a holistic view of energy use and emissions for policy planning;

- Helping identify both strengths and weaknesses in performance and enabling factors;

- Supporting data-driven decision-making by highlighting data availability gaps;

Providing openings for discussions on whether the metrics used in the CCE Index are appropriate for the

- national context in question and what alternatives exist, including sector and organization-level metrics;

- Spurring discussions around optimal policies, technologies, and other enabling factors at the country level. 


\section{Scoring system}

The CCE Index scores countries on a scale of 0-100. Scores are applied both at the indicator and index/sub-index levels. A country's score should be interpreted as an indication of how close it is to ideal performance, either compared with its top-ranking peers or a technical optimum. In other words, a score of 66 , for example, would equal two-thirds of a potential maximum score. The CCE Index also provides a rank for each country at the index and sub-index levels to facilitate comparisons across countries.

The 2021 edition of the CCE Index comprises a total of 47 indicators. Eight indicators measure performance, and 29 measure enabling factors. Separate scores are first calculated for the performance and enablers scores, which are then aggregated to form the total CCE Index score. In total, the CCE Index therefore consists of three aggregate scores: the CCE Performance score, the CCE Enablers score, and the total CCE Index score.

Ten oil producer-specific indicators, referred to as the Oil Producers Lens, are applied to major oil-producing countries to form three additional scores: the Oil Producers Lens Performance score, the Oil Producers Lens Enablers score, and the Oil Producers Lens total score.

Figure 2 illustrates the indicator framework of the 2021 CCE Index.

Figure 2. 2021 CCE Index indicator framework.

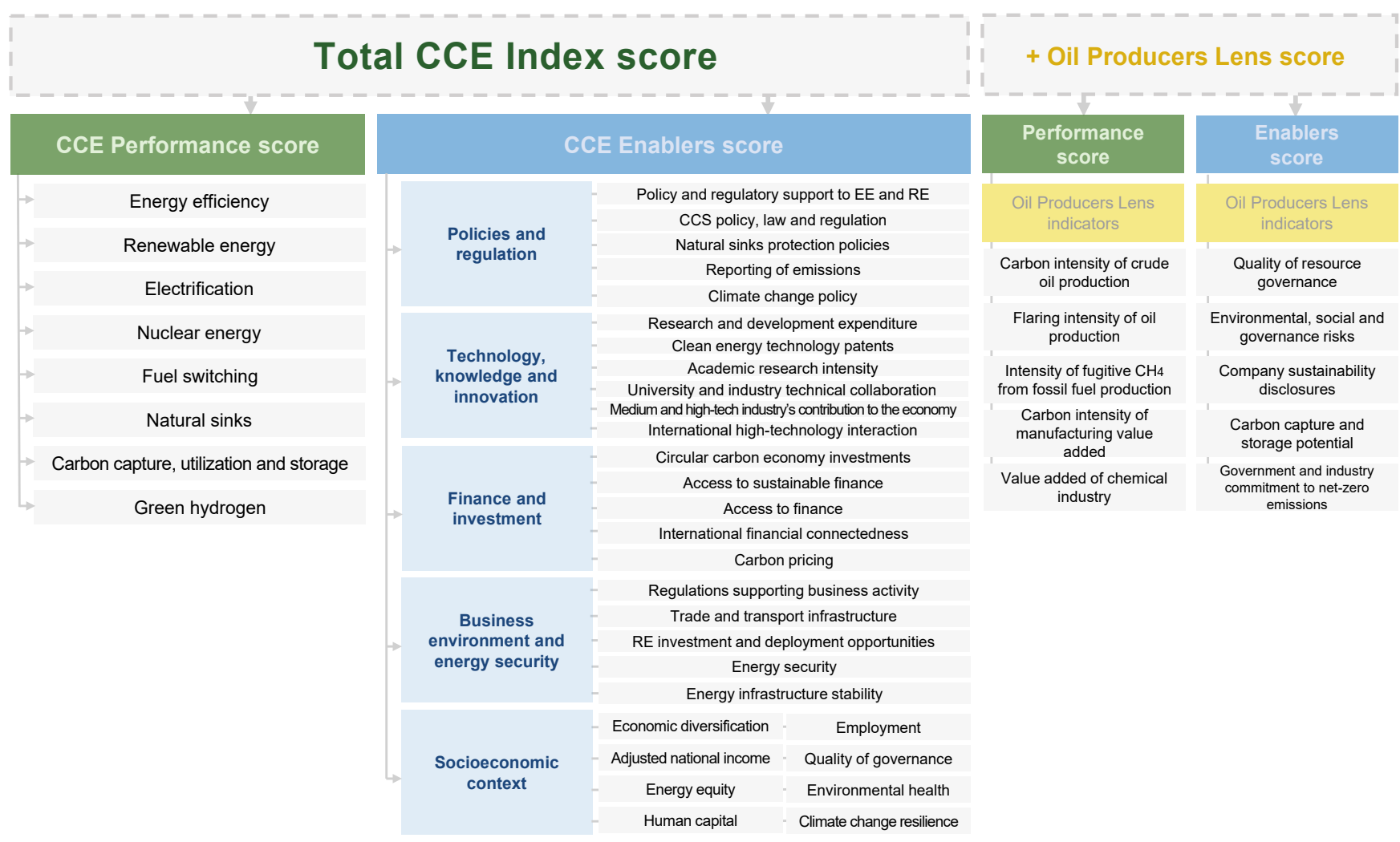

Source: Authors. 


\section{Methodology}

$\mathbf{T}$ The CCE Index has been designed following international best practice in composite indicator development for country comparisons (incl. Eurostat [2014], [2017a-b]; JRC [2004]; Lafortune et al. [2018]; OECD [2008]; UNECE [2019]). The adopted approach is described in more detail in Appendix 2 of the KAPSARC paper, "The Circular Carbon Economy Index - Methodological Approach and Conceptual Framework" (Luomi et al. 2021), which describes the general framework for the construction of the CCE Index.

This section presents the methodological steps taken and choices made, following the broad categories identified in the aforementioned KAPSARC framing paper: the conceptual framework; data selection; data preparation and processing; validation; and stakeholder engagement. The paper also identifies ways to expand and refine the index in future editions. Detailed information about the 2021 edition is included in the tables within this section and in the appendices.

\section{The conceptual framework}

The CCE Index consists of two main sub-indices: Performance and Enablers. No country has yet reached a circular carbon economy, and it is therefore important not only to measure where countries currently stand but also to estimate their potential to move toward carbon circularity by mid-century.
Performance sub-index and scores: While emission-based metrics might seem the obvious choice for measuring carbon circularity, they add little value in terms of indicating how countries are achieving related outcomes. Staying true to the early conceptualizations of the CCE, as laid out by McDonough (2016), Williams (2019), KAPSARC (2020), Mansouri et al. (2020), Al Saud and Al Shalan (2020), IEF (2020), IEEJ (2021) and others, the CCE Index emphasizes holistic, pragmatic and cost-effective approaches to reducing and avoiding emissions. Most of these authors have framed the CCE through the main mitigation or emissions management technologies, policies and options, which are divided into the 'four Rs' - reduce, recycle, reuse, and remove. Figure 3 presents some of the main CCE conceptualizations to date. While the CCE Index accommodates all of these taxonomies, when it is necessary to classify a CCE activity, it follows the conceptualization from KAPSARC (2020). 
Figure 3. Main CCE conceptualizations.

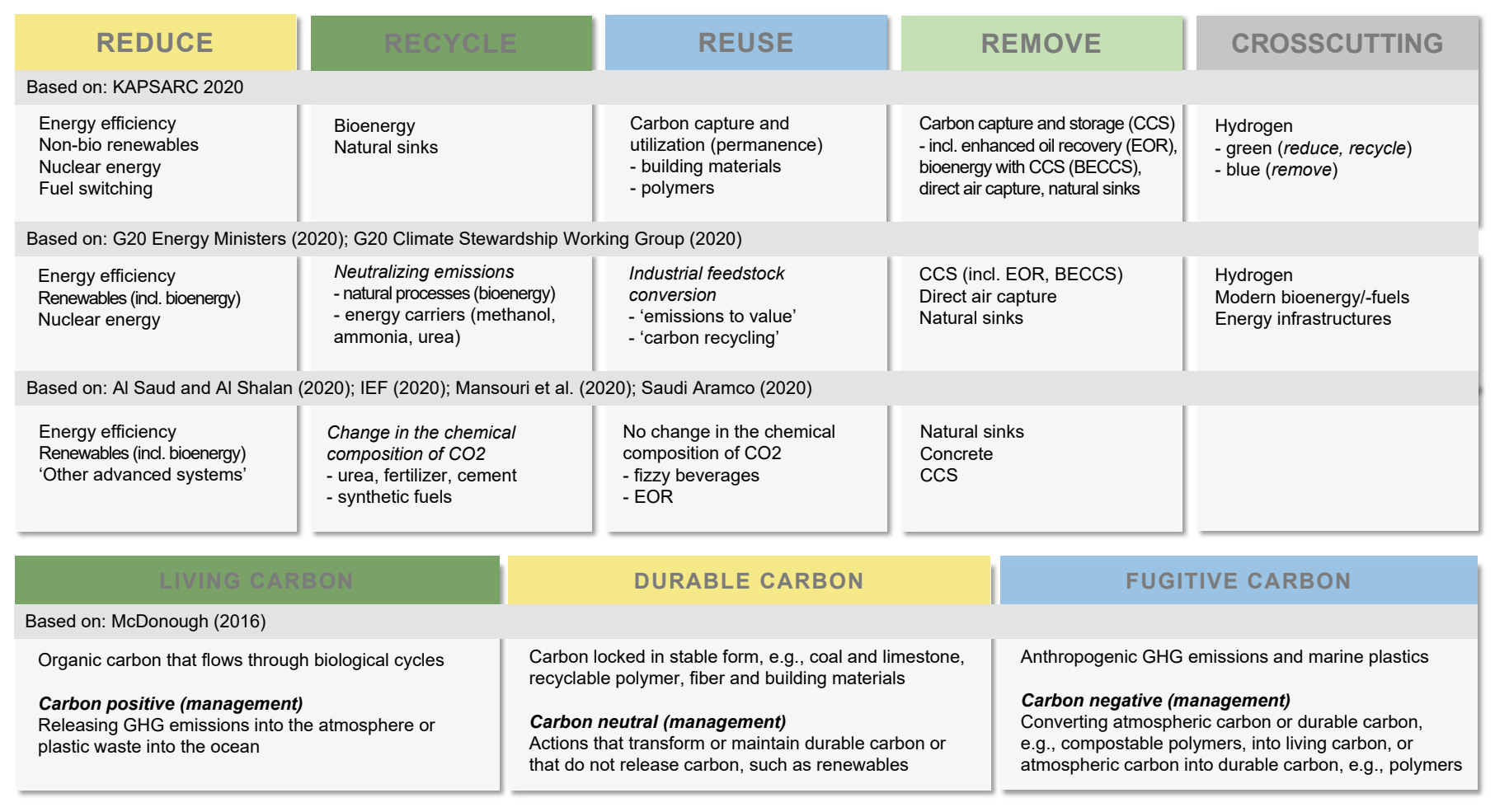

Source: Adapted from Luomi et al. (2021).

To accommodate the fact that different authors and actors place different technologies and options under different Rs, the index framework does not include the R-based categories. Instead, the index compiles the core CCE activities, on which all conceptualizations agree, side by side (see Figures 1 and 2). The main criteria for developing the components of the Performance sub-index, therefore, was whether a technology or emissions management/reduction option helps prevent atmospheric emissions of carbon dioxide (CO2) or other greenhouse gases (GHG). Avoiding and reducing these emissions both in the short and medium term will be key to keeping within the remaining global carbon budget and achieving the goals of the Paris Agreement.

There are two observations to be made on the interpretation of the Performance sub-index results.
The first relates to the challenge of creating a standardized weighting scheme for measuring the different CCE activities. Existing CCE literature emphasizes that approaches should be determined by countries' national circumstances, including their natural resource endowments and development needs and strategies (e.g., Williams [2019]). For example, one country may opt for an approach predominantly based on energy efficiency and renewables, whereas another country may be able to expand its natural sinks, and yet another will be well-placed for large-scale CCS deployment or hydrogen production.

The challenge is that it is not possible to construct a universal formula that would allow for substitution across the performance indicators to reflect this diversity of possible CCE pathways at the country level. We have therefore opted to give all 
Performance indicators an equal weight. This leads to the Performance sub-index rewarding countries that are adopting a variety of CCE approaches.

The main argument in support of this choice is that it is commonly agreed that reducing emissions will require a diversity of approaches - the famous 'silver buckshot.' The Performance sub-index, therefore, should be interpreted as an indicator of both countries' overall performance across the different CCE activities, including crosscutting ones, and the diversity of these engagements.

The second observation relates to a gap in the current indicator framework. A core feature of the CCE conceptual literature is its emphasis on value creation: in a CCE, carbon can also generate economic value as long as atmospheric CO2 emissions are avoided (McDonough 2016). Focusing on the 'economy' in the 'circular carbon economy,' the Performance sub-index should also measure how countries are capturing economic value from carbon circularity. However, some of the main applications in this area that relate to carbon capture and utilization are still not implemented on a large scale. Therefore, this dimension of CCE performance remains to be further developed in future editions of the index (see also Table 4 in the validation section).

\section{Enablers sub-index and scores: The Enablers} sub-index and its five sub-dimensions aim to capture relevant, future-oriented determinants of success in transitioning toward CCEs. The indicator choices were drawn from related literature, and the approach to constructing the sub-dimensions was similar to that taken in other related indices, such as the Energy Transition Index and Energy Trilemma Index (Singh et al. 2019; WEC 2020). The Enablers sub-index is divided into five dimensions:

\section{Policies and regulation}

Technology, knowledge and innovation

Finance and investment

Business environment and energy security

Socioeconomic context

These sub-dimensions are intended to distinguish and measure separate but equally important thematic clusters that provide a comprehensive overview of the enabling factors that support countries in their transition toward CCEs (see Figure 2).

The main methodological observation here relates to the specificity of the indicators. In country comparison indices, the major tradeoff is commonly between the number of countries and the sophistication of indicators. Our goal was to select the most CCE-specific indicators wherever we could. This informed our selection of countries for the first (2021) edition of the index (see below) because more detailed, harmonized data is generally more readily available for major economies.

However, CCE-specific indicators are currently not directly available for many areas, even for the limited group of countries included in the 2021 edition. Many international data providers do not provide technology-based disaggregations for datasets measuring key enabling factors, such as research and development (R\&D) expenditure or foreign direct investment. However, the broader literature on energy transitions provides a rich discussion on close alternatives, many of which are utilized in the index (Bourcet 2020). 
Where CCE-related indicators with sufficient data availability exist, they often only cover activities relevant to the 'reduce' pillar of the CCE, namely renewable energy and, in some cases, energy efficiency. Examples of these include energy technology patents and investments, and enabling business environments. In some areas, data and indicators are emerging that allow enablers relevant to other CCE activities to be measured - the CCS Readiness Index being a leading example (Consoli, Havercroft, and Irlam 2017). However, holistic indicators are still lacking in many areas.

\section{Oil Producers Lens and scores: The Oil}

Producers Lens comprises 10 indicators in the first CCE Index edition: five to measure performance and five to measure enablers. It is intended as a starting point for conversations on ways to measure how countries with large hydrocarbon sectors, many of which are economically reliant on related export industries, can make progress toward CCEs.

Global interest in and the application of hydrocarbon and energy-intensive, industry-specific sustainability standards and metrics have seen a rapid increase in recent years. Related datasets are still fragmented,

Figure 4. Countries included in the 2021 CCE Index. and standardized ways to measure performance and potential are yet to emerge. Therefore the 2021 CCE Index edition should be interpreted as a conversation opener in this space. Future editions will include possible improved metrics and more refined ways to measure the different dimensions the index seeks to capture.

Country selection: To allow for the inclusion of more specific indicators, the CCE Index initially includes countries from two groups: the Group of Twenty (G20) member countries and top-20 oil-producing countries (based on BP 2020, 16). Global datasets often have good coverage for the 19 countries in the former group, and the top-20 oil producers are added to enable context-specific comparisons with a sufficiently large group of countries.

Due to a partial overlap between the two groups, 30 countries are included in the 2021 edition. We set a requirement of at least $80 \%$ of indicator data coverage for any country included, which Libya (a top-20 oil producer) did not fulfill. Figure 4 shows the countries included in the 2021 CCE Index. The number of countries may be expanded in future editions.

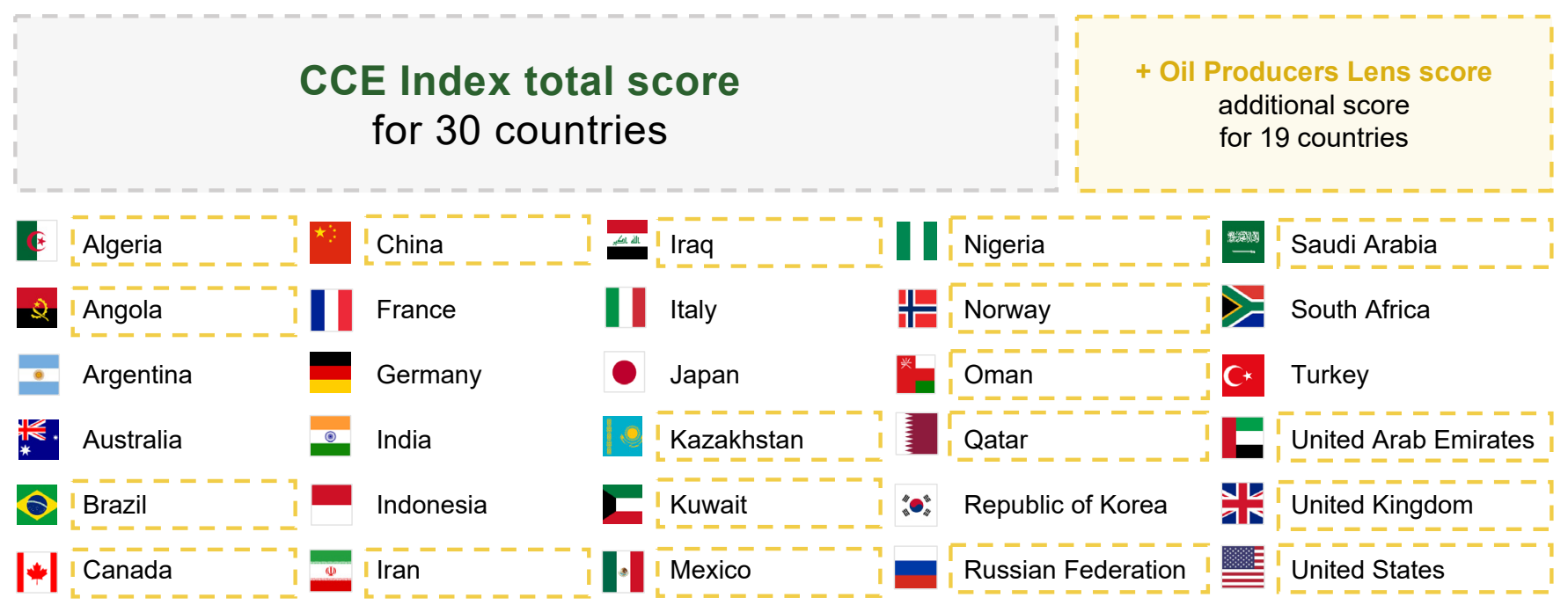

Source: Authors. 


\section{Data selection}

Below, we outline the criteria developed and applied to indicator selection and explain the data sources used. Stakeholder and expert consultations, which informed the indicator selection, are described in the section on stakeholder engagement. For the first (2021) edition of the CCE Index, we reviewed roughly 150 potential variables, which we reduced to 47 variables.

A list of all indicators and related summary statistics, including methodological descriptions, data sources, imputations, scoring logic and links to the aspects of the CCE they seek to measure, are provided in Appendices 1 and 2. An Excel file containing information on the indicators is also made available via the CCE Index website to interested experts and stakeholders.

Selection criteria: The following criteria informed the indicator selection:

Relevance and specificity: The indicator must be conceptually linked to the aspect of the CCE that is being measured.

\section{Simplicity and communicability: The} indicator should be easy to understand and communicate.

Universality: The indicators should be applicable to all or as many countries as possible.

Validity and quality: The data must be from a reliable source and deemed as accurate and reliable.

Availability: Data must be recent (no older than five years, as a rule of thumb), and values must be available for at least $80 \%$ of the countries included in the index. Data should also be imputable for any missing observations.

Transparency and replicability: Datasets used should be open source or otherwise publicly available, or, as a minimum, the data points (values) used in the index should be disclosable.

Relevance and specificity translate differently to the three dimensions of the index. First, for the Performance sub-index, an indicator should be the best possible measure available of how a country is implementing a CCE activity. For some activities, such as renewable energy and energy efficiency, established indicators already exist. For others, activities are still in their early stages and, consequently, fewer datasets are available.

Second, for the Enablers sub-index, relevance means relevance to the sub-dimension (e.g., policy and regulation, or finance and investment) being measured. Preference was given to more specific metrics (e.g., CCE-related energy patent applications instead of total patent applications). The final sub-dimension, which measures socioeconomic enablers, is a partial exception, as it contains a number of more generic measures that are intended to indicate the 'health' of the broader economic, social, environmental and governance context in which CCE transitions are happening.

Third, for the Oil Producers Lens, we emphasized the relevance of indicators to the oil/hydrocarbon sector and related energy-intensive industries.

Other criteria for indicator selection included harmonized datasets: All data must be available from a single source, and additional data points from other sources (such as self-reported national estimates) were not accepted. The availability 
of data over time, in the form of regular future data updates, was also considered: Truncated or terminated variables were avoided to ensure the index can be updated periodically.

Data sources: Data sources included in the 2021

CCE Index include:

Official statistics from the United Nations (U.N.) and other international organizations.

Data, indicators and indices developed by research organizations (including universities, research institutes and reputable consultancies) and published in peer-reviewed academic publications.

Data and indicators generated by reputable corporate data providers.
Table 1 shows the source organizations/authors of the indicators used in the 2021 CCE Index. More source and methodological information on each indicator is available in Appendix 1 and via the CCE Index web portal.

Table 1. Data sources used in the 2021 CCE Index.

\begin{tabular}{l|l}
\multicolumn{1}{c|}{ Type of data source } & $\begin{array}{l}\text { Data source (organization/author(s) } \\
\text { International Energy Agency; International Labour Organization; International Monetary Fund; } \\
\text { U.N. Department of Economic and Social Affairs; U.N. Educational, Scientific and Cultural } \\
\text { Organization Institute for Statistics; U.N. Framework Convention on Climate Change; U.N. } \\
\text { Industrial Development Organization; World Bank (including the Energy Sector Management } \\
\text { Assistance Program, TCdata360, GovData360, and with the Natural Resource Governance } \\
\text { Institute and Brookings Institute); World Health Organization; World Intellectual Property } \\
\text { Organization (including Cornell University and INSEAD) }\end{array}$ \\
\hline $\begin{array}{l}\text { Data from research } \\
\text { organizations and } \\
\text { peer-reviewed publications }\end{array}$ & $\begin{array}{l}\text { Burck et al. (2020); Eckstein, Künzel, and Schäfer (2021); Energy \& Climate Intelligence Unit } \\
\text { (2021); Global CCS Institute (2021); Global Reporting Initiative (2020); Harvard Growth Lab } \\
\text { (2021); Wendling et al. (2020); World Energy Council (WEC) (2020) }\end{array}$ \\
\hline Data from corporate providers & Bloomberg; Enerdata; EY (2021); GRI (2020); Global Risk Profile (2019)
\end{tabular}


To ensure transparency and replicability, all underlying data (values) and corresponding indicator scores for the 2021 CCE Index are made available for interested experts and users.

Choice of years: As the primary option, the data for the latest available year is selected as the indicator value. Data for most indicators in the 2021 CCE Index framework are for 2018-2021. For some indicators, the indicator values cover a number of years. One justification for doing this was the need to measure change (e.g., fuel switching). In some instances, we employed averages or stocks (sums) of the last three or five years. For example, for finance-related indicators, such as sustainable debt, CCE investment, or stock market capitalization, values may fluctuate significantly in specific years, which could lead to misleading indicator scores. ${ }^{1}$ In one instance (company sustainability disclosures), we included data points from 10 years because of the limited overall number of observations for some countries.

\section{Data coverage requirement exceptions: The} thresholds for indicator inclusion (excluding imputations for other than 0) for the 2021 CCE Index are 24 countries for the global CCE Index and 15 countries for the Oil Producers Lens. Only three exceptions were made:

For "carbon capture and storage policy, law and regulation," which has values for 28 countries for the Policy Indicator component and for 22 countries for the Legal and Regulatory Indicator component, we used imputations received directly from the authors of the indicators.

"Climate change policy," under the policies and regulation sub-dimension, has values for 23 countries. We considered this a central component of this sub-dimension and consider the current indicator, taken from the Climate Change Performance Index, the best available one.
"Access to finance" comprises three variables (domestic credit to the private sector, stock market capitalization, and corporate bond issuance volume) and has data for all variables for 23 countries. For six countries, either one or two values were imputed, and for one country only, data was imputed for all variables.

\section{Data preparation and processing}

Imputations and missing data: The indicator selection methodology already imposes a data coverage rule that minimizes missing observations. For the remaining gaps, we followed a three-step imputation hierarchy for the missing observations:

1. When current observations were unavailable for some countries, we used data from the most recent available year (but generally, data older than five years was not included). ${ }^{2}$

2. In some specific cases where an absence of a value could be interpreted with a high level of confidence as a lack of activity, we imputed 0 for missing values (e.g., 'green hydrogen' or 'carbon capture, utilization and storage' under the Performance sub-index).

3. We then imputed the small number of remaining missing observations using standard statistical techniques followed by similar indices: we split countries into two income groups (middle and high income) and four regions (Americas, South and East Asia and the Pacific, Europe and Central Asia, and the Middle East and Africa), building on World Bank's classifications. We used the average of available data in each income-region strata to impute the missing observations.

As a result, all countries in the 2021 CCE Index have values for all indicators, totaling 1,300 observations. 
Only $5.0 \%$ of the complete dataset for the 2021 edition is imputed. On average, only 1.38 values were imputed at the variable level, and 2.17 at the country level. A total of 31 indicators (66\%) and 10 countries (33\%) have data available for all indicators. Before taking into account imputed zeros, three countries have between eight and 10 imputed values (Angola, Iraq and Nigeria), three countries have five imputed values (Iran, Oman and Qatar), and the remaining 14 countries have between one and four imputed values.

If imputed zeros are excluded, only $2.4 \%$ of the complete dataset is imputed, and no single country has more than six imputed values. A detailed imputation map is presented in Appendix 3. Imputed values are indicated by an asterisk whenever indicator values are displayed

Scaling: After imputations, all indicators were scaled to 0-100. The direction was also normalized so that the scale was inverted in indicators in which a decreasing score implied improvement (e.g., energy intensity or the flaring intensity of oil production).

Whenever necessary, we scaled the variables to take into account size-related parameters to avoid related biases. Many indicators are already scaled to size, such as existing index scores, indicators expressed in percentages, and indicators scaled by the data provider (e.g., research and development expenditure/gross domestic product [GDP]). For the remainder, we used either population (e.g., per 100,000 population) or economy size (GDP, purchasing power parity [PPP] in current US\$).

Boundary values: When setting the boundary values for the minimum and maximum scores for each indicator, we used the following hierarchy:
1. Existing indicator scoring ranges (for indicators that originate from existing indices,when appropriate).

2. Technical or otherwise globally accepted limits (e.g., positive values in fuel switching for changes in oil and coal use equal to a zero score).

3. An average of the lowest and highest values:

a. For the global indicators, the minimum (min.)/maximum (max.) scores are calculated from the average of the three bottom/top values (i.e., the $10 \%$ percentile);

b. For the oil producers lens indicators, the min./max. scores are calculated from the average of the two bottom/top values (i.e., the $10 \%$ percentile).

When applying the third method (average of top/ bottom performers), for some indicators, we excluded outliers that would have distorted the results. One example is the lowest value in "intensity of fugitive methane emissions from fossil fuel production" (0.138), which was 24 times smaller than the next smallest value (3.254) and 190 times smaller than the highest value (26.125).

The min./max. values and justifications for each variable are listed in Appendix 1.

Retaining a positive relation: In order to ensure a positive relation between the indicators and their targeted concepts, we inverted the rescaled variables where necessary. For instance, for the energy efficiency indicator, measured by the energy intensity of the economy, a higher value implies lower energy efficiency. For indicators like this, we subtracted the rescaled score from 100, where the new (inverted) variable gives a higher score for 
higher performance.

Weighting and aggregation: After testing for different aggregation methods (see the section on validation), we opted for simple averaging for aggregation, which implies equal weighting for each indicator. This is a common practice used in socioeconomic composite indicators that measure multidimensional concepts (UNECE 2019, 78). It also allows for easy and transparent communication of the weighting and aggregation methodology to all types of target audiences.

In the Performance sub-index, each indicator receives an equal weight, and the score is calculated as a simple average of all indicators.

In the Enablers sub-index, each indicator initially receives an equal weight, and the sub-dimension scores are calculated as a simple average of their respective indicators. The sub-dimensions are then aggregated to the sub-index level by simple averaging (arithmetic mean).

Each sub-dimension is intended to measure what we deem as a key aspect of enabling factors for CCE transitions: policies and regulation; technology, knowledge and innovation; finance and investment; enabling business environments and infrastructure; and general socioeconomic enablers. To avoid taking a stance on the relative importance of each of the five areas and to avoid introducing implicit weights for sub-dimensions with more indicators, each sub-dimension receives an equal weight when aggregating to the sub-index level.

The total CCE Index score comprises a simple average of the Performance and Enablers sub-index scores. The same rationale for equal weighting applies here: The two sub-indices are intended to measure two conceptual dimensions - the present and the future. The number of indicators under each sub-index should therefore not affect the score.

The Oil Producers Lens includes five indicators on the Performance sub-index side and five indicators on the Enablers sub-index side. For the Oil Producers Lens Performance score, we first calculate a simple average of the Oil Producers Lens indicators, and then aggregate this with the total CCE Index score via a simple average of the two scores.

For the Oil Producers Lens Enablers score, we first calculate a simple average of the Oil Producers Lens indicators, and then calculate a new simple average of the six sub-dimensions (now including the Oil Producers Lens enablers as asubdimension). Similar to the total CCE Index score, the Oil Producers Lens total score is calculated as a simple average of the Oil Producers Lens Performance and Enablers scores.

Figure 5 illustrates the weighting and aggregation logic of the 2021 CCE Index. 
Figure 5. Aggregation and weighting logic of the 2021 CCE Index.

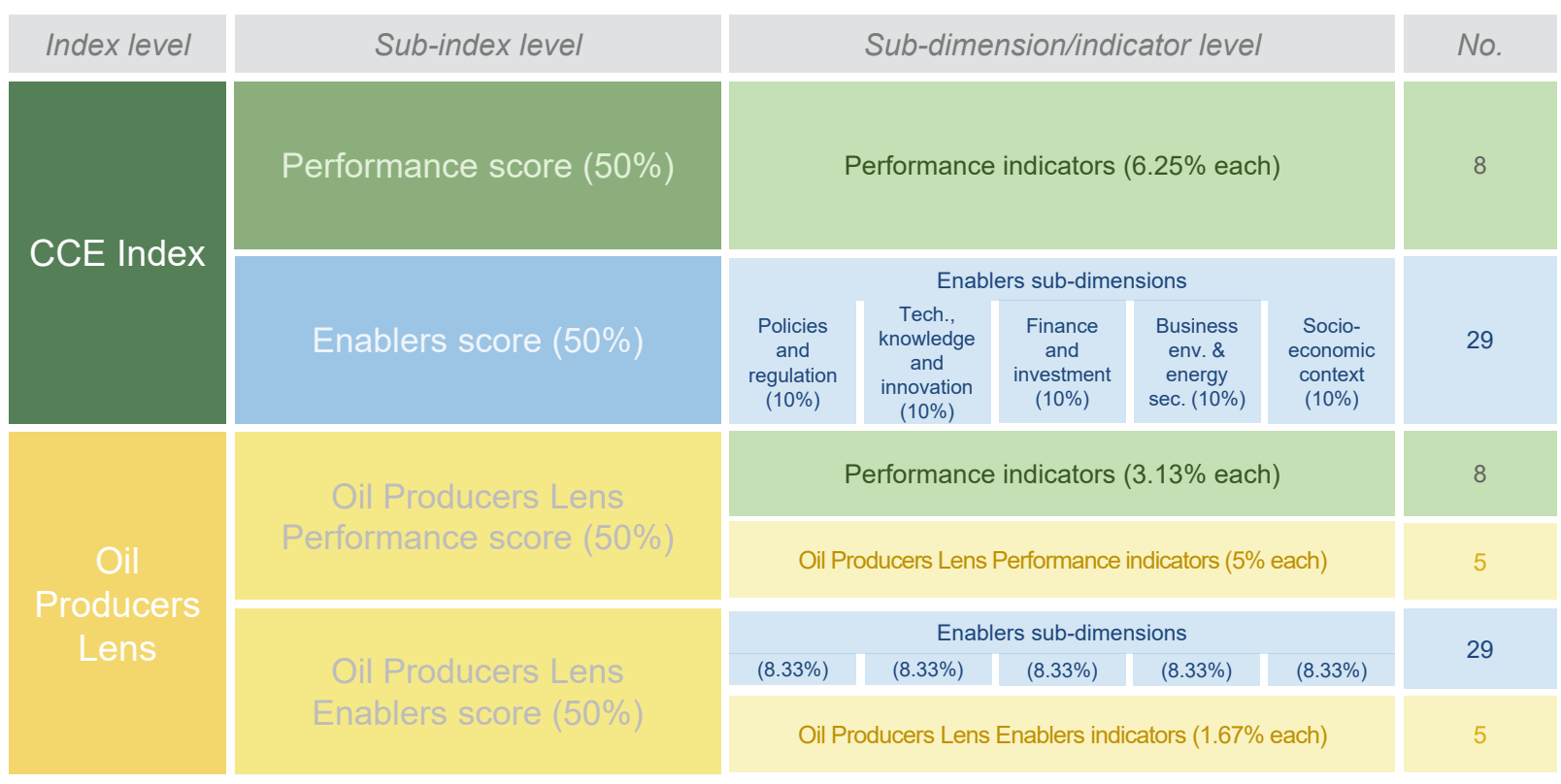

Source: Authors.

\section{Validation}

In line with best practice, we tested the assumptions associated with the modeling process and the decisions adopted in the creation of the CCE Index through various validation checks. The validation covered three areas: robustness, cross-validity analysis, and links to other statistics.

Robustness: First, we analyzed how changes in the aggregation method affected the results, which provides information on the robustness of the index methodology. We considered two alternative aggregation methods: geometric averaging and principal component analysis (PCA). Since the CCE's holistic approach gives countries full flexibility in selecting different clean technologies, applying geometric averaging in the aggregation would have undermined this principle. This is because geometric averaging cannot accommodate zero scores (so-called corner solutions) in the indicator values and penalize uneven performance across the different CCE activities.

PCA provides some useful features for our validation purposes. The PCA methodology relies on common behavior (i.e., correlations) across the indicators, which would imply that, for instance, in order to score high on the Performance sub-index, a country would need to follow a common trend across the measured CCE activities. While some common patterns may exist in performance across the different activities, imposing this condition would not have been in line with the CCE's emphasis on diverse and varied approaches. We therefore applied PCA only to the Enablers sub-index, where one would expect to see countries with high CCE potential tending to receive high scores in all the enabler dimensions. We also tested the total CCE Index score, but not the Performance sub-index score alone. 
We adopted PCA and associated weights in aggregating the enabling indicators to re-compute the enablers sub-index scores $\left(E_{\mathrm{pca}}\right){ }^{3}$ We then aggregated $\mathrm{ES}_{\mathrm{pca}}$ with the original performance scores (PSe, computed via equal weighting) to get the composite CCE Index scores using equal weights $\left(C C E_{p c a}\right)$. The results from this analysis yield a strong correlation with the baseline scores (around 99\%), with minimal changes in country rankings displayed in Figure 6. As shown in the figure, applying PCA to the Enablers sub-index causes no or minimal change $( \pm 1)$ in the rankings of most countries (24 countries out of 30 ).

Cross-validity analysis: Ensuring that the CCE Index measures its intended conceptual focus is another crucial validity test. If the correlations between the individual indicators and the aggregated indicators are 1 (or above 0.9 according to Lafortune et al. [2018]), then a multicollinearity problem would arise. This would imply that some of the indicators or aggregated indicators are redundant or capture their conceptual focus weakly. Table 2 presents the correlations across all the aggregated sub-indices and indicators and provides a check for multicollinearity.

As shown in the table, we do not observe multicollinearity. It is worth noting that correlations across the performance indicators (Table 2 ii) are particularly low, and indicate different signs and weak statistical significance. These differences imply variant trajectories that countries follow, given their local specificities and the availability of different low-carbon technologies, which is precisely the underlying logic of the CCE.

Figure 6. Changes in rankings when using PCA in aggregation (number of countries).
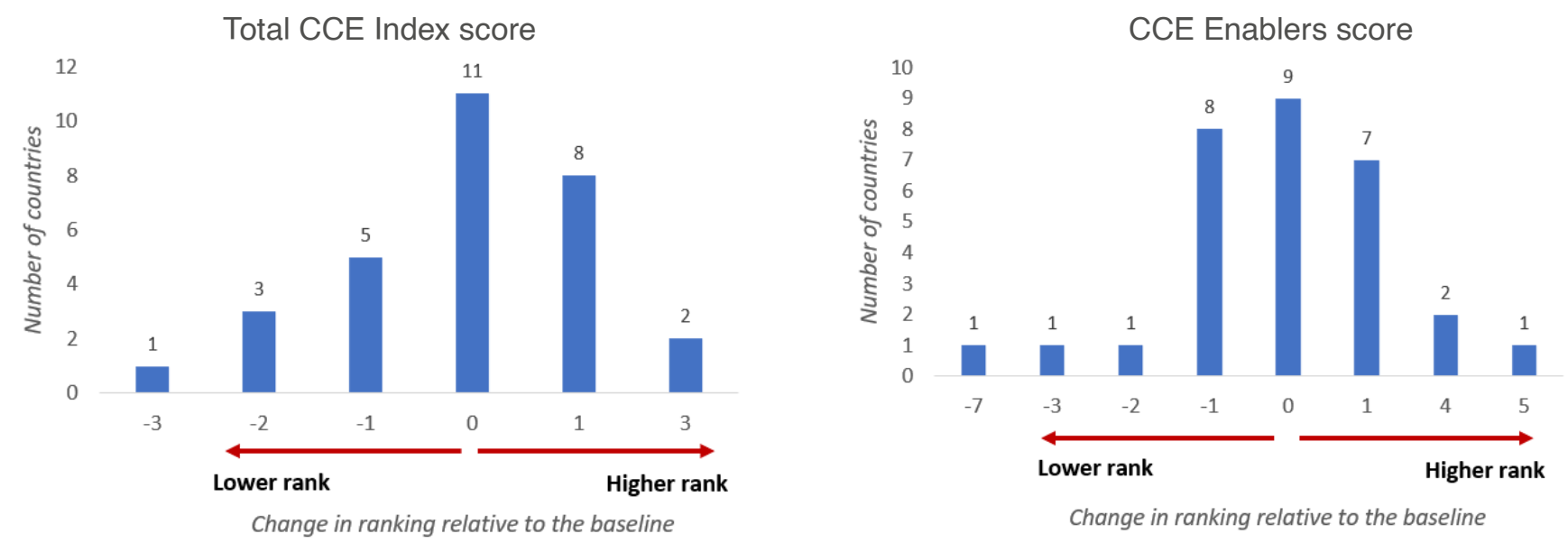

Source: Authors' calculations. 
Table 2. Correlation matrices across aggregated sub-indices and indicators.

(i) Aggregated sub-indices

\begin{tabular}{|c|c|c|c|c|c|c|c|c|c|}
\hline & & 1 & 2 & 3 & 4 & 5 & 6 & 7 & 8 \\
\hline 1 & Performance score & 1.00 & & & & & & & \\
\hline 2 & Oil Producers Lens (performance) & 0.44 & 1.00 & & & & & & \\
\hline 3 & Policy and Regulation score & 0.77 & 0.31 & 1.00 & & & & & \\
\hline 4 & Technology, Knowledge and Innovation & 0.62 & 0.50 & 0.79 & 1.00 & & & & \\
\hline 5 & Finance and Investment & 0.76 & 0.44 & 0.86 & 0.82 & 1.00 & & & \\
\hline 6 & Business Environment and Energy Security & 0.55 & 0.55 & 0.78 & 0.83 & 0.79 & 1.00 & & \\
\hline 7 & Socioeconomics Enablers & 0.48 & 0.43 & 0.70 & 0.79 & 0.81 & 0.79 & 1.00 & \\
\hline 8 & Oil Producers Lens (enablers) & 0.79 & 0.54 & 0.81 & 0.81 & 0.90 & 0.75 & 0.84 & 1.00 \\
\hline
\end{tabular}

${ }^{*}$ Bold numbers are statistically significant at least at the $10 \%$ confidence level.

(ii) Performance indicators

\begin{tabular}{|c|c|c|c|c|c|c|c|c|c|}
\hline & & 1 & 2 & 3 & 4 & 5 & 6 & 7 & 8 \\
\hline 1 & inv_mmx_pf_ee & 1.00 & & & & & & & \\
\hline 2 & mmx_pf_re & 0.43 & 1.00 & & & & & & \\
\hline 3 & mmx_pf_electricity & 0.22 & -0.16 & 1.00 & & & & & \\
\hline 4 & mmx_pf_nuclear & 0.08 & -0.11 & 0.36 & 1.00 & & & & \\
\hline 5 & inv_mmx_pf_fswitch & 0.17 & 0.04 & -0.19 & 0.13 & 1.00 & & & \\
\hline 6 & mmx_pf_natlsinks & -0.42 & -0.48 & -0.19 & -0.36 & 0.25 & 1.00 & & \\
\hline 7 & mmx_pf_ccus & 0.04 & 0.20 & 0.31 & 0.22 & 0.13 & -0.03 & 1.00 & \\
\hline & mmx_pf_h2 & 0.28 & 0.21 & 0.29 & 0.07 & -0.01 & -0.07 & 0.28 & 1.00 \\
\hline
\end{tabular}

*Bold numbers are statistically significant at least at the $10 \%$ confidence level. "inv_" implies inverted variable, "mmx_" implies min/ max adjusted, "op_" implies oil producer lens and "_imp" implies the variable contains imputed values.

(iii) Oil Producers Lens (performance)

\begin{tabular}{|c|c|c|c|c|c|c|}
\hline & & 1 & 2 & 3 & 4 & 5 \\
\hline 2 & inv_mmx_pf_op_flaring & 0.67 & 1.00 & & & \\
\hline 3 & inv_mmx_pf_op_ch4fug & 0.57 & 0.73 & 1.00 & & \\
\hline 4 & inv_mmx_pf_op_co2mva & 0.07 & 0.22 & 0.44 & 1.00 & \\
\hline
\end{tabular}

*Bold numbers are statistically significant at least at the $10 \%$ confidence level. "inv_" implies inverted variable, "mmx_" implies min/ max adjusted, "op_" implies oil producer lens and “_imp" implies the variable contains imputed values. 
(iv) Policy and Regulation sub-dimension indicators

\begin{tabular}{|c|c|c|c|c|c|c|}
\hline & & 1 & 2 & 3 & 4 & 5 \\
\hline 1 & mmx_eb_pol_ccs & 1.00 & & & & \\
\hline 2 & mmx_eb_pol_cpol_imp & 0.24 & 1.00 & & & \\
\hline 3 & mmx_eb_pol_rise_imp & 0.67 & 0.37 & 1.00 & & \\
\hline 4 & mmx_eb_pol_mrv & 0.76 & 0.11 & 0.70 & 1.00 & \\
\hline & mmx_eb_pol_kbas & 0.41 & 0.18 & 0.35 & 0.37 & 1.00 \\
\hline
\end{tabular}

*Bold numbers are statistically significant at least at the 10\% confidence level. "inv_" implies inverted variable, "mmx_" implies min/max adjusted, "op_" implies oil producer lens and "_imp" implies the variable contains imputed values.

(v) Technology, Knowledge and Innovation sub-dimension indicators

\begin{tabular}{|c|c|c|c|c|c|c|c|}
\hline & & 1 & 2 & 3 & 4 & 5 & 6 \\
\hline 1 & mmx_eb_tki_rd_imp & 1.00 & & & & & \\
\hline 2 & mmx_eb_tki_htechtrade_imp & 0.68 & 1.00 & & & & \\
\hline 3 & mmx_eb_tki_nindex & 0.77 & 0.43 & 1.00 & & & \\
\hline 4 & mmx_eb_tki_unvindcol & 0.66 & 0.44 & 0.70 & 1.00 & & \\
\hline 5 & mmx_eb_tki_iva & 0.72 & 0.56 & 0.51 & 0.66 & 1.00 & \\
\hline & mmx_eb_tki_pate & 0.87 & 0.56 & 0.61 & 0.49 & 0.64 & 1.00 \\
\hline
\end{tabular}

*Bold numbers are statistically significant at least at the $10 \%$ confidence level. "inv_" implies inverted variable, "mmx_" implies min/max adjusted, "op_" implies oil producer lens and “_imp” implies the variable contains imputed values.

(vi) Finance and Investment sub-dimension indicators

\begin{tabular}{|c|c|c|c|c|c|c|}
\hline & & 1 & 2 & 3 & 4 & 5 \\
\hline 1 & mmx_eb_fin_cp & 1.00 & & & & \\
\hline 2 & mmx_eb_fin_sdeb & 0.55 & 1.00 & & & \\
\hline 3 & mmx_eb_fin_fdi & 0.28 & 0.43 & 1.00 & & \\
\hline 4 & mmx_eb_fin_inv & 0.56 & 0.75 & 0.44 & 1.00 & \\
\hline & mmx_eb_fin_acctofin & 0.56 & 0.51 & 0.42 & 0.69 & 1.00 \\
\hline
\end{tabular}

*Bold numbers are statistically significant at least at the 10\% confidence level. "inv_" implies inverted variable, "mmx_" implies min/max adjusted, "op_" implies oil producer lens and "_imp" implies the variable contains imputed values. 
(vii) Business Environment and Energy Security sub-dimension indicators

\begin{tabular}{|c|c|c|c|c|c|c|}
\hline & & 1 & 2 & 3 & 4 & 5 \\
\hline & mmx_eb_bei_eob & 1.00 & & & & \\
\hline & mmx_eb_bei_lpi & 0.83 & 1.00 & & & \\
\hline 3 & mmx_eb_bei_recai & 0.56 & 0.54 & 1.00 & & \\
\hline 4 & inv_mmx_eb_bei_ensec & 0.00 & -0.15 & -0.18 & 1.00 & \\
\hline & inv_mmx_eb_bei_stability_imp & 0.61 & 0.56 & 0.29 & 0.22 & 1.00 \\
\hline
\end{tabular}

*Bold numbers are statistically significant at least at the $10 \%$ confidence level. "inv_" implies inverted variable, "mmx_" implies min/max adjusted, "op_" implies oil producer lens and “_imp” implies the variable contains imputed values.

(viii) Socioeconomics Enablers sub-dimension indicators

\begin{tabular}{|c|c|c|c|c|c|c|c|c|c|}
\hline & & 1 & 2 & 3 & 4 & 5 & 6 & 7 & 8 \\
\hline 1 & mmx_eb_see_gov & 1.00 & & & & & & & \\
\hline 2 & mmx_eb_see_crisk & 0.05 & 1.00 & & & & & & \\
\hline 3 & mmx_eb_see_eci_imp & 0.58 & -0.32 & 1.00 & & & & & \\
\hline 4 & mmx_eb_see_employ & 0.31 & 0.31 & 0.03 & 1.00 & & & & \\
\hline 5 & mmx_eb_see_equity & 0.49 & 0.29 & 0.38 & 0.20 & 1.00 & & & \\
\hline 6 & mmx_eb_see_hci & 0.76 & 0.03 & 0.72 & 0.32 & 0.71 & 1.00 & & \\
\hline 7 & mmx_eb_see_pollution & -0.64 & -0.06 & -0.50 & -0.09 & -0.78 & -0.78 & 1.00 & \\
\hline 8 & mmx_eb_see_agni & 0.86 & 0.20 & 0.43 & 0.47 & 0.57 & 0.72 & -0.59 & 1.00 \\
\hline
\end{tabular}

*Bold numbers are statistically significant at least at the $10 \%$ confidence level. "inv_" implies inverted variable, "mmx_" implies min/max adjusted, "op_" implies oil producer lens and "_imp" implies the variable contains imputed values.

(ix) Oil Producers Lens (enablers)

\begin{tabular}{|c|c|c|c|c|c|c|}
\hline & & 1 & 2 & 3 & 4 & 5 \\
\hline 1 & mmx_eb_op_storage & 1.00 & & & & \\
\hline 2 & inv_mmx_eb_op_esgrisk & 0.72 & 1.00 & & & \\
\hline 3 & mmx_eb_op_rgi & 0.41 & 0.55 & 1.00 & & \\
\hline & mmx_eb_op_netzero & 0.66 & 0.75 & 0.64 & 1.00 & \\
\hline & mmx_eb_op_sddisc & 0.33 & 0.55 & 0.20 & 0.33 & 1.00 \\
\hline
\end{tabular}

*Bold numbers are statistically significant at least at the $10 \%$ confidence level. "inv_" implies inverted variable, "mmx_" implies min/max adjusted, "op_" implies oil producer lens and "_imp" implies the variable contains imputed values. 
Links to other statistics: The aim of the CCE index is to measure countries' performance in and potential for achieving an objective related to a complex and multidimensional concept, which cannot be observed directly. Comparing the indicator either to a reference series or to other relevant statistics can provide measures of how well the index measures and represents the CCE concept.

Since the CCE Performance sub-index aims to capture countries' performance on a variety of carbon circularity approaches and technologies, one can expect a negative correlation between high index scores and country-level $\mathrm{CO} 2$ metrics. Given the CCE's focus on the economy, a comparison of the carbon intensity of economies is particularly relevant.

Of relevance for the CCE Enablers sub-index are a number of indices that focus on capturing different aspects of global energy transitions (Narula and Reddy 2015). Two of these indices, in particular, have captured a high degree of attention in global policy discussions: the World Economic Forum's Energy Transition Index and the World Energy
Council's Trilemma Index (see Singh et al. [2019] and WEC [2020] for more details). The Energy Transition Index benchmarks countries based on their current energy system performance and readiness for energy transitions. The Energy Trilemma Index aims to capture countries' energy system performance by measuring how they balance three competing dimensions of energy policy (security, sustainability and equity) amid global energy transitions. While these two indices have a more general focus on energy transitions, they share common concepts with the CCE Enablers sub-index, which is the forward-looking component of the CCE Index. One, therefore, would expect to observe strong positive correlations between the CCE index and the two aforementioned indices.

Table 3 shows the correlations between the different aggregations of the CCE index and CO2 intensity to GDP, the Energy Transition Index and the Energy Trilemma Index. The results show that countries with high CCE scores tend to record lower $\mathrm{CO} 2$ intensities, in particular on the CCE Performance score, which is the most directly related to countries' carbon circularity performance. Similarly, there is a sizable positive correlation between the CCE index and the other relevant index scores.

Table 3. Correlations with the reference series and other indices.

\begin{tabular}{lccc} 
& $\begin{array}{c}\text { CO2 intensity to GDP (in } \\
\text { current US\$) } 2019\end{array}$ & $\begin{array}{c}\text { Energy Transition } \\
\text { Index 2020 }\end{array}$ & $\begin{array}{c}\text { Energy Trilemma } \\
\text { Index 2020 }\end{array}$ \\
\hline Total CCE Index score & -0.67 & 0.90 & 0.81 \\
CCE Index Performance score & -0.75 & 0.87 & 0.69 \\
CCE Index Enablers score & -0.54 & 0.86 & 0.86 \\
Oil Producers Lens total score & -0.61 & 0.70 & 0.77 \\
Oil Producers Lens Performance score & -0.67 & 0.91 & 0.58 \\
Oil Producers Lens Enablers score & -0.47 & 0.84 \\
\hline
\end{tabular}

Source: Authors' calculations, based on Enerdata (2021); WEF (2020); WEC (2020). All correlations are statistically significant at the $1 \%$ confidence level. 


\section{Stakeholder engagement}

For transparency and to ensure a robust indicator framework, the index developers engaged

stakeholders and experts in the following ways:

\section{Consultations with experts and data providers:}

The index team exchanged emails and held videoconferences with several dozen data providers (e.g., organizations, companies, or researchers who have developed/maintain a dataset, indicator or index) and experts on specific dimensions of the index (e.g., hydrogen, natural sinks, or greenhouse gas accounting) to improve the understanding of data definitions, methodological approaches and choices, possible data quality issues, and their overall relevance to the index. These exchanges greatly informed the indicator selection process.

Group consultations: Through September 2021, the index team reached out to intended index users in Saudi Arabia and various developing countries through workshops and invitations. We solicited input on the conceptual framework and indicator selection, with the aim of gauging their relevance for policymakers and other stakeholders. A KAPSARC Workshop Brief from September 2021 contains the proceedings of one of these events (Luomi, Yilmaz, and Alshehri 2021b). Stakeholder engagements will continue and be expanded to more countries in the dissemination phase and future update cycles.

\section{Quality assurance via an advisory committee:} From August 2021 onward, based on feedback received from the expert exchanges, KAPSARC set up and convened the International Technical Advisory Committee for the CCE Index. The core index team engaged the five initial members of this committee to help improve the quality of the indicator framework by providing expert-based feedback and reviewing this methodology paper. Box 2 explains the objectives and purpose of the advisory committee.

Box 2: The CCE Index International Technical Advisory Committee.

The CCE Index International Technical Advisory Committee comprises a group of internationally renowned experts in relevant fields, serving on a pro bono basis in individual capacities. Its purpose is to help support the delivery of a robust index and its dissemination.

The main activities of the Committee members are providing expert feedback and inputs on, inter alia, methodological choices, substantive issues pertaining to each member's area of expertise, and the overall indicator framework and index methodology. Members will also share their suggestions for the next edition of the index, including relating to new datasets and research. Committee members also contribute to the dissemination of the index.

In its initial year, 2021-2022, the Committee includes five senior researchers, academics and subject matter experts representing four world regions and five countries.

A similar consultative approach will be applied to future editions of the CCE Index. Regular reviews and revisions of the indicator framework by a broad group of stakeholders and experts will help ensure that the index measures what it is intended to measure and incorporates the best available indicators and data for doing this 


\section{Future editions}

The CCE Index indicator framework is designed to be adapted over time to ensure its relevance to users by accommodating evolutions in the concept of the CCE, new datasets and ways to measure the CCE, and improvements in data availability. The CCE is a new concept, and the technologies and activities underpinning it are in many cases only starting to be scaled up worldwide. It is our hope that the CCE Index will help initiate conversations on these three dimensions, namely what carbon circularity means for different countries, how to best measure related progress and enablers, and what can be done to improve data development, quality and transparency.

Because the CCE Index is designed to be revised and updated periodically, index results will not be directly comparable across different years. However, we may include data on trends in individual indicators in future editions. This will allow us to observe countries' progress over time in the various dimensions of the index.

We may also include a larger group of countries in future editions. A further possibility is to include an Oil Importers Lens to mirror the Oil Producers Lens.

\section{Gaps identified and scope for future revisions:}

Throughout the development of the indicator framework and via the consultations detailed above, we identified various components of CCE performance and enablers for which we were unable to find suitable or the most ideal indicators. We classified these into six types:

1. In a limited number of cases, where we had previously identified an indicator as core to the conceptual framework, we considered an absence of indicators as actual gaps in the indicator framework. These cases include carbon capture and utilization (CCU) applications (in the performance sub-index) and measurements of CCU-related value generation (in the oil-producers performance lens). The activities in these two areas are not yet large-scale enough to have been captured in international, harmonized datasets, but we expect more data to become available as interest in these applications increases and implementation picks up. The same applies to other carbon removal technologies, such as direct air capture, for example.

2. In some cases, we opted to use datasets/ indicators even if they were not $100 \%$ complete or where we identified some room for further methodological robustness. In these cases, we felt it would be more meaningful to include the data to incentivize discussions around improved data availability and quality, rather than not to measure the component at all.

3. In many cases, we opted to use more generic indicators that we feel provide a sufficiently good proxy for more CCE-specific aspects of the same component. We may replace these indicators with more specific ones in future editions if we identify new, suitable datasets. There were also areas where we could not measure the different dimensions of the CCE in a balanced way, but decided it was important to include an existing specific measure to draw attention to the gap and encourage further data to be made available.

4. We also identified a number of possible further ways to measure CCE performance or enablers for which we expect datasets to be available in the near future. 
5. We concluded that some indicators were not a good fit for the indicator framework in its first edition. Examples included indicators that measure a less significant or too narrow an aspect of CCE performance or enablers, or where activities are not yet scaled up sufficiently.

6. There may be datasets accessible by subscription only that we are unaware of, and naturally, the same may apply to some open-access datasets or indicators.

The CCE Index indicator framework is not static; it is designed to be continuously improved through future editions as new or better datasets become available and based on feedback received from users and other stakeholders. Table 4 presents the main 'gaps' and identifies possible areas for future refinement and expansion of the CCE Index.

Table 4. Potential components for future expansion and refinement of the CCE Index.

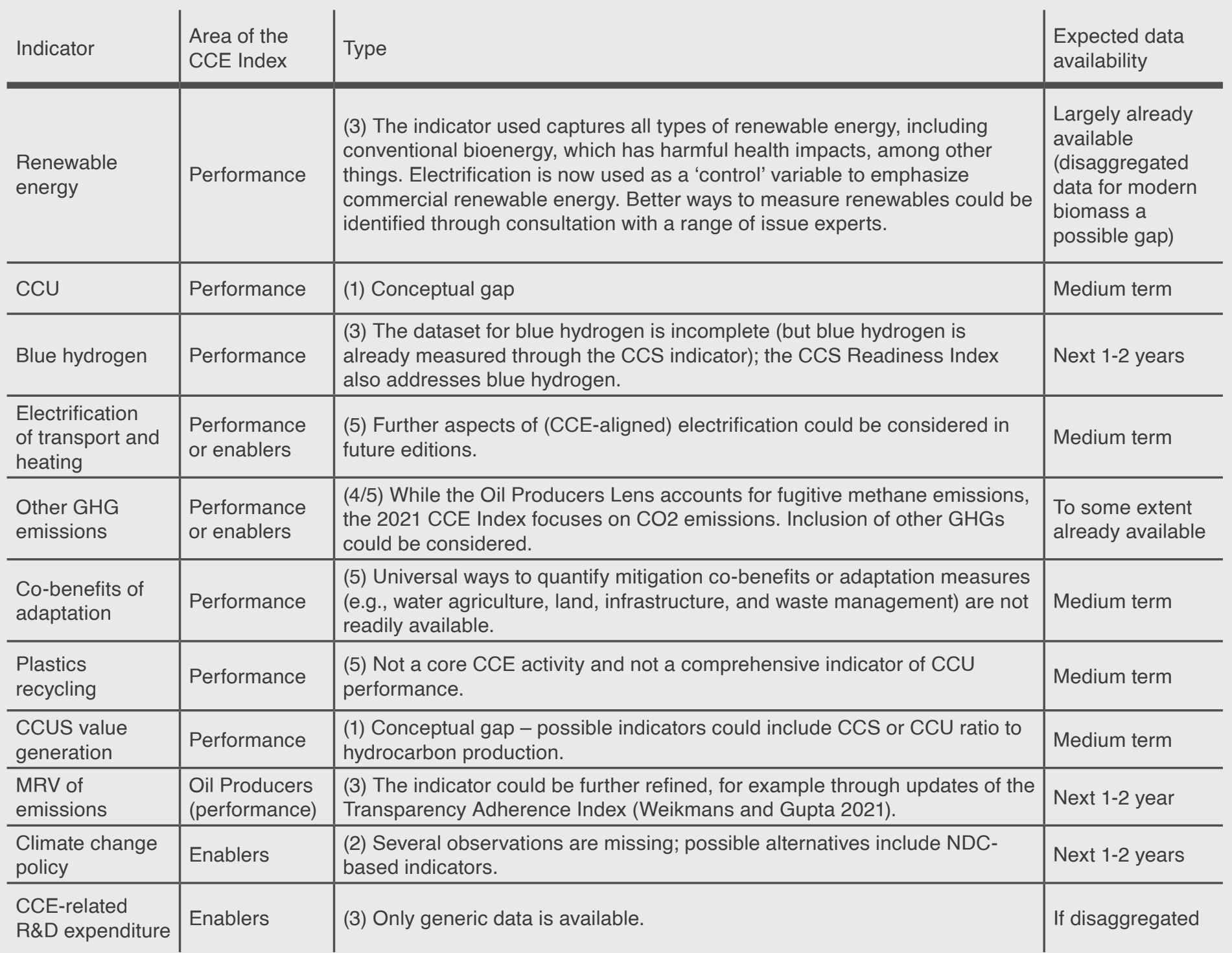


Table 4. Potential components for future expansion and refinement of the CCE Index.

\begin{tabular}{|c|c|c|c|}
\hline Indicator & $\begin{array}{l}\text { Area of the } \\
\text { CCE Index }\end{array}$ & Type & $\begin{array}{l}\text { Expected data } \\
\text { availability }\end{array}$ \\
\hline $\begin{array}{l}\text { CCUS-related } \\
\text { patents }\end{array}$ & Enablers & $\begin{array}{l}\text { (3) The current indicator does not cover all CCE-relevant patent } \\
\text { applications. }\end{array}$ & If disaggregated \\
\hline CCE financing & Enablers & $\begin{array}{l}\text { (2) There are gaps in country coverage for areas other than renewables } \\
\text { (CCS, hydrogen etc.). }\end{array}$ & Next $1-2$ years \\
\hline $\begin{array}{l}\text { CCE investment } \\
\text { frameworks }\end{array}$ & Enablers & $\begin{array}{l}\text { (2) The methodology of the current indicator is not peer-reviewed; (3) } \\
\text { there are no indicators for areas of the CCE other than renewables. }\end{array}$ & Medium term \\
\hline $\begin{array}{l}\text { Electric vehicle } \\
\text { (EV)-related } \\
\text { indicators }\end{array}$ & Enablers & $\begin{array}{l}\text { (4) Future indicator(s) could include EV infrastructure density, EV stock } \\
\text { density and/or EV-to-charger rations. }\end{array}$ & Next $1-2$ years \\
\hline $\begin{array}{l}\text { Green hydrogen } \\
\text { price }\end{array}$ & Enablers & (4) Robust datasets were not identified. & Next $1-2$ years \\
\hline Energy storage & Enablers & $\begin{array}{l}\text { (6) Data may be available through subscription; possible indicators } \\
\text { could include grid energy storage, lithium mining activity, battery cell } \\
\text { manufacturers and/or rare earth or mineral prices. }\end{array}$ & $\begin{array}{l}\text { Depending on } \\
\text { access }\end{array}$ \\
\hline $\begin{array}{l}\text { CCE-related } \\
\text { employment }\end{array}$ & Enablers & (3) Data is only available for employment in the renewables sector. & If disaggregated \\
\hline $\begin{array}{l}\text { Carbon and } \\
\text { sustainability } \\
\text { disclosures, } \\
\text { environmental, } \\
\text { social and } \\
\text { government } \\
\text { (ESG) factors, } \\
\text { industry climate } \\
\text { targets }\end{array}$ & $\begin{array}{l}\text { Oil Producers } \\
\text { (enablers) }\end{array}$ & $\begin{array}{l}\text { (2) Existing datasets are fragmented, but interest in related metrics/ } \\
\text { frameworks is increasing rapidly; indicators can be refined/ defined } \\
\text { further, including as better data(sets) become available. }\end{array}$ & Medium term \\
\hline $\begin{array}{l}\text { Various } \mathrm{CO}_{2-} \\
\text { based metrics }\end{array}$ & Performance & $\begin{array}{l}\text { (5) CO2-based metrics are reserved primarily for the validation of the } \\
\text { index. }\end{array}$ & Already available \\
\hline $\begin{array}{l}\text { Economic } \\
\text { sector-based } \\
\text { metrics }\end{array}$ & $\begin{array}{l}\text { Performance/ } \\
\text { enablers }\end{array}$ & $\begin{array}{l}\text { (5) Sector-based metrics were excluded to keep the number of indicators } \\
\text { manageable for easier communication. }\end{array}$ & $\begin{array}{l}\text { In some cases } \\
\text { already available }\end{array}$ \\
\hline $\begin{array}{l}\text { Oil Importers } \\
\text { Lens }\end{array}$ & $\begin{array}{l}\text { Performance/ } \\
\text { enablers }\end{array}$ & $\begin{array}{l}\text { (5) This idea came up toward the end of the index development process, } \\
\text { but it can be explored in future editions. }\end{array}$ & $\begin{array}{l}\text { Most likely } \\
\text { already available }\end{array}$ \\
\hline
\end{tabular}




\section{Appendix 1.2021 CCE Index codebook}

\begin{tabular}{|c|c|c|c|c|c|c|c|c|c|c|c|c|c|}
\hline 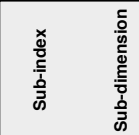 & 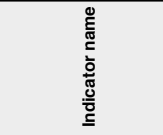 & 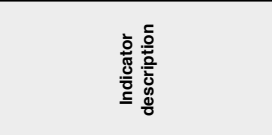 & 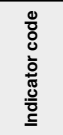 & $\frac{0}{5}$ & ஹั & $\frac{\vec{g}}{5}$ & 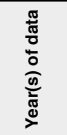 & 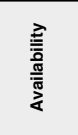 & $\dot{\Sigma}$ & $\sum_{\substack{x \\
\tilde{m}}}$ & 这 & 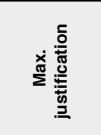 & 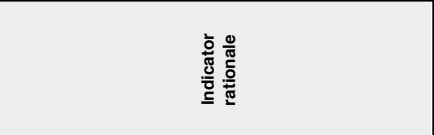 \\
\hline \multirow[t]{8}{*}{$\begin{array}{l}\text { PERFOR- (n/a) } \\
\text { MANCE }\end{array}$} & Energy efficiency & $\begin{array}{l}\text { Energy intensity of the GDP at } \\
\text { purchasing power parities }\end{array}$ & pf_ee & $\begin{array}{l}\text { koe/2015 } \\
\text { US\$ PPP }\end{array}$ & $\begin{array}{l}\text { Enerdata } \\
(2021)\end{array}$ & $\begin{array}{l}\text { https://global- } \\
\text { energy- } \\
\text { data.enerdata } \\
\text {.net/database/ }\end{array}$ & 2019 & 30 & 0.218 & 0.061 & $\begin{array}{l}\text { Average of } \\
\text { bottom-3 } \\
\text { performers }\end{array}$ & $\begin{array}{l}\text { Average of } \\
\text { top-3 } \\
\text { performers }\end{array}$ & $\begin{array}{l}\text { Energy intensity is the most commonly-used measure of } \\
\text { energy efficiency, which in turn helps reduce CO2/GHG } \\
\text { emissions. }\end{array}$ \\
\hline & Renewable energy & $\begin{array}{l}\text { Share of renewables in primary } \\
\text { consumption }\end{array}$ & pf_re & $\%$ & $\begin{array}{l}\text { Enerdata } \\
(2021)\end{array}$ & $\begin{array}{l}\text { https://global- } \\
\text { energy- } \\
\text { data.enerdata } \\
\text { net/database/ }\end{array}$ & 2019 & 30 & 0.01 & 46.31 & $\begin{array}{l}\text { Average of } \\
\text { bottom-3 } \\
\text { performers }\end{array}$ & $\begin{array}{c}\text { Average of } \\
\text { top-3 } \\
\text { performers } \\
\text { (1 outlier } \\
\text { excluded })\end{array}$ & $\begin{array}{l}\text { Renewable energy is a key contributor to circular carbon } \\
\text { economies as it helps reduce (non-bio renewables) and } \\
\text { recycle (bio renewables) CO2/GHG emissions. }\end{array}$ \\
\hline & Electrification & $\begin{array}{l}\text { Share of electricity in total final } \\
\text { energy consumption }\end{array}$ & $\begin{array}{l}\text { pf_ele } \\
\text { ctricity }\end{array}$ & & $\begin{array}{l}\text { Enerdata } \\
(2021)\end{array}$ & $\begin{array}{l}\text { https://global- } \\
\text { energy- } \\
\text { data.enerdata } \\
\text { net/database/ }\end{array}$ & 2019 & 30 & 7.19 & 25.77 & $\begin{array}{l}\text { Average of } \\
\text { bottom-3 } \\
\text { performers }\end{array}$ & $\begin{array}{l}\text { Average of } \\
\text { top-3 } \\
\text { performers } \\
\text { (1 outlier } \\
\text { excluded) }\end{array}$ & $\begin{array}{l}\text { Electrifying sectors beyond the power sector, including } \\
\text { transport and heating (e.g., via electric vehicles and heat } \\
\text { pumps) with modern renewable energy, is considered } \\
\text { crucial for reducing emissions. At present, renewable } \\
\text { energy is mainly used for power generation. In the CCE } \\
\text { Index, electrification is used to account for the fact that } \\
\text { in many countries a large share of renewable energy is } \\
\text { still generated from traditional biomass, which generally } \\
\text { has adverse health impacts and often contributes to } \\
\text { deforestation. }\end{array}$ \\
\hline & Nuclear energy & $\begin{array}{l}\text { Share of nuclear electricity in } \\
\text { primary consumption }\end{array}$ & $\begin{array}{l}\text { pf_nu } \\
\text { clear }\end{array}$ & $\%$ & $\begin{array}{l}\text { Enerdata } \\
(2021)\end{array}$ & $\begin{array}{l}\text { https://global- } \\
\text { energy- } \\
\text { data.enerdata } \\
\text { net/database/ }\end{array}$ & 2019 & $\begin{array}{l}27(3 \\
\text { imputed } \\
\text { as } 0)\end{array}$ & 0 & 10.56 & $\begin{array}{l}\text { Average of } \\
\text { bottom-3 } \\
\text { performers }\end{array}$ & $\begin{array}{l}\text { Average of } \\
\text { top-3 } \\
\text { performers } \\
\text { (1 outlier } \\
\text { excluded })\end{array}$ & $\begin{array}{l}\text { Nuclear energy contributes to circular carbon } \\
\text { economies by helping to reduce emissions. }\end{array}$ \\
\hline & Fuel switching & $\begin{array}{l}\text { Change in the share of oil, coal } \\
\text { and lignite and derived gas in } \\
\text { electricity production over a five- } \\
\text { year period, and overall share of } \\
\text { oil, coal, lignite and derived gas in } \\
\text { electricity production at the start of } \\
\text { the period }\end{array}$ & $\begin{array}{l}\text { pf_fs } \\
\text { witchi } \\
\text { ng }\end{array}$ & $\begin{array}{l}\text { percent } \\
\text { points } \%\end{array}$ & $\begin{array}{l}\text { Enerdata } \\
(2021)\end{array}$ & $\begin{array}{l}\text { https://global- } \\
\text { energy- } \\
\text { data.enerdata } \\
\text {.net/database/ }\end{array}$ & $\begin{array}{l}2014- \\
2019\end{array}$ & 30 & 80.53 & -26.62 & 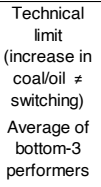 & $\begin{array}{l}\text { Average of } \\
\text { top-3 } \\
\text { performers }\end{array}$ & $\begin{array}{l}\text { Switching towards lower-carbon energy sources helps } \\
\text { avoid and reduce emissions, and is therefore is crucial } \\
\text { in transitions toward circular carbon economies. Most } \\
\text { changes are currently happening in the power sector. In } \\
\text { the CCE Index, the fuel switching indicator also acts as } \\
\text { a control for electrification, as it penalises countries with } \\
\text { high shares of coal and oil in the power mix. }\end{array}$ \\
\hline & Natural sinks & $\begin{array}{l}\text { Ecosystem services, including } \\
\text { carbon sequestration and storage, } \\
\text { biodiversity habitat, nutrient } \\
\text { cycling, and coastal protection } \\
\text { (from the Environmental } \\
\text { Performance Index) }\end{array}$ & $\begin{array}{l}\text { pf_nat } \\
\text { Isinks }\end{array}$ & $\begin{array}{l}\text { Score 0- } \\
100\end{array}$ & $\begin{array}{l}\text { Wendling et } \\
\text { al., (2020) }\end{array}$ & $\begin{array}{l}\text { hitps://epi.yale } \\
\text {.edu/epi- } \\
\text { results/2020/c } \\
\text { omponent/ecs }\end{array}$ & 2020 & $\begin{array}{l}29(1 \\
\text { imput- } \\
\text { ed) }\end{array}$ & 20.3 & 100 & $\begin{array}{l}\text { Rescaled } \\
\text { based on } \\
\text { sample } \\
\text { minimum }\end{array}$ & $\begin{array}{l}\text { Rescaled } \\
\text { based on } \\
\text { sample } \\
\text { maximum }\end{array}$ & $\begin{array}{l}\text { Net carbon stored in natural sinks contributes to the } \\
\text { remove pillar of the circular carbon economy. Nature- } \\
\text { based solutions, however, run the risk of releasing } \\
\text { carbon into the atmosphere through fires, for example, } \\
\text { which is why they are considered an important } \\
\text { complementary option. }\end{array}$ \\
\hline & $\begin{array}{l}\text { Carbon capture, } \\
\text { utilization and } \\
\text { storage }\end{array}$ & $\begin{array}{l}\text { Total capture capacity of CCUS } \\
\text { projects (operational, in } \\
\text { construction, advanced } \\
\text { development and early } \\
\text { development) }\end{array}$ & $\begin{array}{l}\text { pf_cc } \\
\text { us }\end{array}$ & $\begin{array}{l}\text { MtCO2/y } \\
\text { ear/GDP } \\
2019, \text { bn } \\
\text { current } \\
\text { PPP US\$ }\end{array}$ & $\begin{array}{l}\text { Bloomberg } \\
\text { (2021) }\end{array}$ & $\begin{array}{l}\text { https://mw.bn } \\
\text { ef.com/ }\end{array}$ & $\begin{array}{c}\text { Sep } \\
2021 \\
\text { (status) }\end{array}$ & $\begin{array}{l}23(7 \\
\text { imputed } \\
\text { as } 0)\end{array}$ & 0 & 0.015 & $\begin{array}{l}\text { Average of } \\
\text { bottom-3 } \\
\text { performers }\end{array}$ & $\begin{array}{l}\text { Average of } \\
\text { top-3 } \\
\text { performers }\end{array}$ & $\begin{array}{l}\text { Carbon capture, utilization and storage (CCUS) } \\
\text { contributes to circular carbon economies via the } \\
\text { remove pillar. Enhanced oil recovery (EOR) with } \mathrm{CO} 2 \text { is } \\
\text { included as most of the } \mathrm{CO} 2 \text { injected in most projects } \\
\text { ends up being permanently stored over their lifetimes. }\end{array}$ \\
\hline & Green hydrogen & $\begin{array}{l}\text { Total capacity of green hydrogen } \\
\text { projects (commissioned, } \\
\text { financed/under construction, and } \\
\text { announced/planning begun) }\end{array}$ & pf_h2 & $\begin{array}{l}\text { MWe } \\
\% / G D P \\
2019, \text { bn } \\
\text { current } \\
\text { PPP US\$ }\end{array}$ & $\begin{array}{l}\text { Bloomberg } \\
\text { (2021) }\end{array}$ & $\begin{array}{l}\text { https://mww.bn } \\
\text { ef.com/ }\end{array}$ & $\begin{array}{c}\text { Sep } \\
2021 \\
\text { (status) }\end{array}$ & $\begin{array}{l}17(13 \\
\text { imputed } \\
\text { as } 0)\end{array}$ & 0 & 2.06 & $\begin{array}{l}\text { Average of } \\
\text { bottom-3 } \\
\text { performers }\end{array}$ & $\begin{array}{l}\text { Average of } \\
\text { top-3 } \\
\text { performers } \\
\text { (1 outlier } \\
\text { excluded) }\end{array}$ & $\begin{array}{l}\text { Green hydrogen contributes to circular carbon } \\
\text { economies by helping reduce emissions. Blue hydrogen } \\
\text { also supports circular carbon economies through } \\
\text { remove, but it is covered under CCUS projects. }\end{array}$ \\
\hline
\end{tabular}

\begin{tabular}{|c|c|c|c|c|c|c|c|c|c|c|c|c|c|c|}
\hline 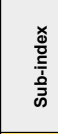 & 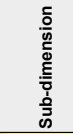 & 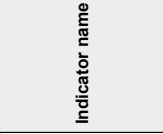 & 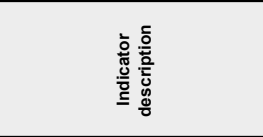 & 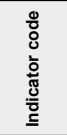 & $\frac{\mathscr{n}}{5}$ & 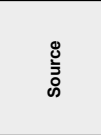 & $\stackrel{\vec{v}}{丂}$ & 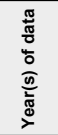 & $\frac{\sqrt{2}}{\frac{\sqrt{2}}{\sqrt{\frac{\pi}{\pi}}}}$ & $\dot{\Sigma}$ & 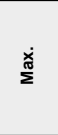 & 竞 & 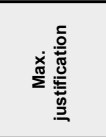 & 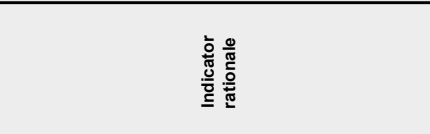 \\
\hline \multirow[t]{5}{*}{$\begin{array}{l}\text { OIL } \\
\text { PRO- } \\
\text { DUC- } \\
\text { ERS } \\
\text { LENS }\end{array}$} & \multirow[t]{5}{*}{$\begin{array}{l}\text { Perfor- } \\
\text { mance }\end{array}$} & $\begin{array}{l}\text { Carbon intensity of } \\
\text { crude oil production }\end{array}$ & $\begin{array}{l}\text { Volume-weighted average carbon } \\
\text { intensity of crude oil production, } \\
\text { transportation and refining by } \\
\text { source country (Source Country } \\
\text { Upstream \& Refining Combined } \\
\text { Cl) }\end{array}$ & $\begin{array}{l}\text { pf_op } \\
\text { co2i } \\
\text { nt }\end{array}$ & $\begin{array}{l}\mathrm{g} / \mathrm{CO} 2 \mathrm{eq} \\
\mathrm{MJ}-1\end{array}$ & $\begin{array}{l}\text { Jing et al. } \\
(2020)\end{array}$ & $\begin{array}{l}\text { https://mww.na } \\
\text { ture.com/articl } \\
\text { es/s41558- } \\
020-0775-3\end{array}$ & 2015 & 19 & 25.65 & 11.80 & $\begin{array}{l}\text { Average of } \\
\text { bottom-2 } \\
\text { performers }\end{array}$ & $\begin{array}{l}\text { Average of } \\
\text { top-2 } \\
\text { performers }\end{array}$ & $\begin{array}{l}\text { Lower carbon intensity of crude oil production } \\
\text { contributes to the reduce pillar of the circular carbon } \\
\text { economy. }\end{array}$ \\
\hline & & $\begin{array}{l}\text { Flaring intensity of } \\
\text { oil production }\end{array}$ & $\begin{array}{l}\text { Gas flared per barrel of oil } \\
\text { produced }\end{array}$ & $\begin{array}{l}\text { pf_op } \\
\text { flarin } \\
g\end{array}$ & $\mathrm{~m} 3 / \mathrm{b}$ & $\begin{array}{l}\text { World Bank } \\
\text { (2021) }\end{array}$ & $\begin{array}{l}\text { https://mww.gg } \\
\text { frdata.org//\#in } \\
\text { dicators-by- } \\
\text { country }\end{array}$ & 2020 & 19 & 18.18 & 0.44 & $\begin{array}{l}\text { Average of } \\
\text { bottom-2 } \\
\text { performers }\end{array}$ & $\begin{array}{l}\text { Average of } \\
\text { top-2 } \\
\text { performers }\end{array}$ & $\begin{array}{l}\text { The less flaring the oil industry generates, the better it is } \\
\text { delivering towards both the reduce pillar of circular } \\
\text { carbon economies and capturing value from this natural } \\
\text { resource. }\end{array}$ \\
\hline & & $\begin{array}{l}\text { Intensity of fugitive } \\
\text { methane emissions } \\
\text { from fossil fuel } \\
\text { production }\end{array}$ & $\begin{array}{l}\text { Fugitive methane emissions from } \\
\text { fossil fuel industry/total fossil fuel } \\
\text { production }\end{array}$ & $\begin{array}{l}\text { pf_op } \\
\text { ug } c \text { 4f }\end{array}$ & $\begin{array}{l}\mathrm{KtCH} 4 / \mathrm{mt} \\
\text { oe }\end{array}$ & IEA (2020) & $\begin{array}{l}\text { http://wds.iea. } \\
\text { org/ }\end{array}$ & 2018 & 19 & 21.33 & 3.49 & $\begin{array}{l}\text { Average of } \\
\text { bottom-2 } \\
\text { performers }\end{array}$ & $\begin{array}{l}\text { Average of } \\
\text { top-2 } \\
\text { performers } \\
\text { (1 outlier } \\
\text { excluded) }\end{array}$ & $\begin{array}{l}\text { The less fugitive emissions the fossil fuel industry } \\
\text { generates, the better it is delivers on both the reduce } \\
\text { pillar of circular carbon economies and capturing value } \\
\text { from these natural resources. }\end{array}$ \\
\hline & & $\begin{array}{l}\text { Carbon intensity of } \\
\text { manufacturing value } \\
\text { added }\end{array}$ & $\begin{array}{l}\mathrm{CO} 2 \text { emissions per unit of } \\
\text { manufacturing value added }\end{array}$ & $\begin{array}{l}\text { pf_op } \\
\text { co2 } \\
\text { mva }\end{array}$ & $\begin{array}{l}\mathrm{kgCO} 2 / \mathrm{c} \\
\text { onstant } \\
2015 \\
\text { US } \$\end{array}$ & $\begin{array}{l}\text { UNSTATS } \\
(2021) / \\
\text { UNIDO } \\
(2021) \text { and } \\
\text { IEA (2020) }\end{array}$ & $\begin{array}{l}\text { https://unstats } \\
\text { un.org/sdgs/i } \\
\text { ndicators/data } \\
\text { base/ }\end{array}$ & 2018 & 19 & 2.47 & 0.12 & $\begin{array}{l}\text { Average of } \\
\text { bottom } 2 \\
\text { performers }\end{array}$ & $\begin{array}{l}\text { Average of } \\
\text { top-2 } \\
\text { performers }\end{array}$ & $\begin{array}{l}\text { This indicator measures the carbon intensity of the } \\
\text { energy mix used in the manufacturing sector, the } \\
\text { structure of the sector, the energy efficiency of } \\
\text { production technologies, and the economic value of the } \\
\text { various outputs. }\end{array}$ \\
\hline & & $\begin{array}{l}\text { Value added of } \\
\text { chemical industry }\end{array}$ & $\begin{array}{l}\text { Value added of chemical industry } \\
\text { as a share of the GDP }\end{array}$ & $\begin{array}{l}\text { pf_op } \\
\text { che } \\
\text { mval }\end{array}$ & $\%$ & $\begin{array}{l}\text { World Bank } \\
\text { (2021) }\end{array}$ & $\begin{array}{l}\text { https://data.w } \\
\text { orldbank.org/i } \\
\text { ndicator/NV. } \\
\text { MNF.CHEM. } \\
\text { ZS.UN }\end{array}$ & $\begin{array}{l}2016- \\
2018 \\
\text { (latest } \\
\text { avail- } \\
\text { able) }\end{array}$ & $\begin{array}{l}17(2 \\
\text { imput- } \\
\text { ed) }\end{array}$ & 0.28 & 3.62 & $\begin{array}{l}\text { Average of } \\
\text { bottom-2 } \\
\text { performers }\end{array}$ & $\begin{array}{l}\text { Average of } \\
\text { top-2 } \\
\text { performers }\end{array}$ & $\begin{array}{l}\text { This indicator acts as an infrastructure-based proxy for } \\
\text { circular carbon economy-related value generation. }\end{array}$ \\
\hline
\end{tabular}




\begin{tabular}{|c|c|c|c|c|c|c|c|c|c|c|c|c|c|c|}
\hline 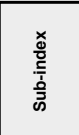 & 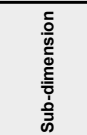 & 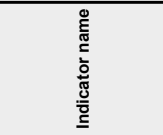 & 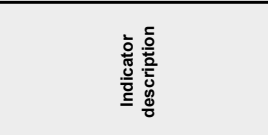 & 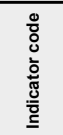 & 总 & 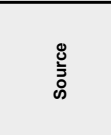 & $\stackrel{\vec{p}}{\underline{s}}$ & 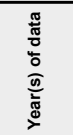 & 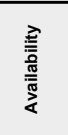 & $\dot{\Sigma}$ & $\sum_{\Sigma}^{x}$ & 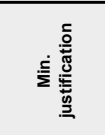 & 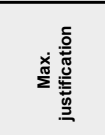 & 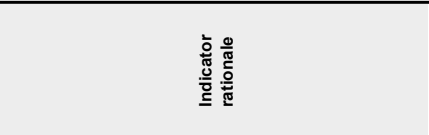 \\
\hline \multirow[t]{5}{*}{$\begin{array}{l}\text { EN- } \\
\text { ABLERS }\end{array}$} & \multirow[t]{5}{*}{$\begin{array}{l}\text { Policies } \\
\text { and regu- } \\
\text { lation }\end{array}$} & $\begin{array}{l}\text { Policy and } \\
\text { regulatory support to } \\
\text { energy efficiency } \\
\text { and renewable } \\
\text { energy }\end{array}$ & $\begin{array}{l}\text { Regulatory Indicators for } \\
\text { Sustainable Energy (RISE) } \\
\text { indicators for energy efficiency } \\
\text { and renewable energy }\end{array}$ & $\begin{array}{l}\text { eb_po } \\
\text { I_rise }\end{array}$ & $\begin{array}{l}\text { Score } 0- \\
100 \\
\text { (average } \\
\text { of the } \\
\text { two) }\end{array}$ & $\begin{array}{l}\text { World Bank } \\
\text { and ESMAP } \\
(2021)\end{array}$ & $\begin{array}{l}\text { https://rise.wo } \\
\text { rldbank.org/sc } \\
\text { ores }\end{array}$ & 2019 & $\begin{array}{l}29(1 \\
\text { imput- } \\
\text { ed) }\end{array}$ & 0 & 100 & $\begin{array}{c}\text { Existing } \\
\text { indicator/ind } \\
\text { ex scoring } \\
\text { range }\end{array}$ & $\begin{array}{l}\text { Existing } \\
\text { indicator/ind } \\
\text { ex scoring } \\
\text { range }\end{array}$ & $\begin{array}{l}\text { The RISE indicators provide a record of laws, } \\
\text { regulations, and policies enacted. They are designed as } \\
\text { a precursor of progress in renewables deployment, } \\
\text { energy efficiency and related investments. }\end{array}$ \\
\hline & & $\begin{array}{l}\text { Carbon capture and } \\
\text { storage policy, law } \\
\text { and regulation }\end{array}$ & $\begin{array}{l}\text { CCS Legal and Regulatory } \\
\text { Indicator and CCS Policy Indicator } \\
\text { (from the CCS Readiness Index) }\end{array}$ & $\begin{array}{l}\text { eb_po } \\
\text { I_ccs }\end{array}$ & $\begin{array}{l}\text { Score } 0- \\
100 \\
\text { (average } \\
\text { of the } \\
\text { two) }\end{array}$ & $\begin{array}{l}\text { Global CCS } \\
\text { Institute } \\
(2021)\end{array}$ & $\begin{array}{l}\text { hitp:///mww.glo } \\
\text { balccsinstitute } \\
\text {.com/resourc } \\
\text { es/publication } \\
\text { s-reports- } \\
\text { research/glob } \\
\text { al-ccs- } \\
\text { institute-ccs- } \\
\text { readiness- } \\
\text { index/ }\end{array}$ & 2021 & $\begin{array}{l}22(8 \\
\text { imput- } \\
\text { ed) }\end{array}$ & 0 & 100 & $\begin{array}{c}\text { Existing } \\
\text { indicator/ind } \\
\text { ex scoring } \\
\text { range }\end{array}$ & $\begin{array}{l}\text { Existing } \\
\text { indicator/ind } \\
\text { ex scoring } \\
\text { range }\end{array}$ & $\begin{array}{l}\text { The Legal and Regulatory Indicator focuses on legal and } \\
\text { regulatory frameworks considered critical for the } \\
\text { domestic regulation of CCS operations. The Policy } \\
\text { Indicator assesses CCS-specific policy measures, } \\
\text { including broader implicit support through measures } \\
\text { including emission reduction targets, carbon pricing and } \\
\text { project funding. }\end{array}$ \\
\hline & & $\begin{array}{l}\text { Natural sinks } \\
\text { protection policies }\end{array}$ & $\begin{array}{l}\text { Average proportion of terrestrial, } \\
\text { freshwater and marine key } \\
\text { biodiversity areas covered by } \\
\text { protected areas }\end{array}$ & $\begin{array}{l}\text { eb_po } \\
\text { I_kbas }\end{array}$ & $\begin{array}{l}\% \\
\text { (average } \\
\text { of three) }\end{array}$ & $\begin{array}{l}\text { UN DESA } \\
(2021) / \\
\text { BirdLife } \\
\text { International, } \\
\text { IUCN and } \\
\text { UNEP- } \\
\text { WCMC } \\
\text { (2019) } \\
\end{array}$ & $\begin{array}{l}\text { https://unstats } \\
\text { un.org/sdgs/i } \\
\text { ndicators/data } \\
\text {, base/ }\end{array}$ & 2020 & 30 & 5.64 & 82.27 & $\begin{array}{l}\text { Average of } \\
\text { bottom-3 } \\
\text { performers }\end{array}$ & $\begin{array}{l}\text { Average of } \\
\text { top-3 } \\
\text { performers }\end{array}$ & $\begin{array}{l}\text { Protected areas play a significant role in sequestering } \\
\text { carbon. Based on some estimates, they sequester one- } \\
\text { fifth of the carbon sequestered by all land ecosystems } \\
\text { annually. }\end{array}$ \\
\hline & & $\begin{array}{l}\text { Reporting of } \\
\text { emissions }\end{array}$ & $\begin{array}{l}\text { Fulfilment of reporting obligations } \\
\text { under the UNFCCC }\end{array}$ & $\begin{array}{l}\text { eb_po } \\
\text { I_mrv }\end{array}$ & $\begin{array}{l}\text { Reports/ } \\
\text { required } \\
\text { reports } \\
\text { (pre- } \\
\text { rescaled } \\
\text { score 0- } \\
\text { 1) } \\
\end{array}$ & $\begin{array}{l}\text { UNFCCC } \\
(2021)\end{array}$ & $\begin{array}{l}\text { https://unfccc. } \\
\text { int/process- } \\
\text { and-meetings }\end{array}$ & $\begin{array}{c}\text { Sep } \\
2021 \\
\text { (status) }\end{array}$ & 30 & 0 & 1.00 & $\begin{array}{l}\text { Technical } \\
\text { minimum }\end{array}$ & $\begin{array}{l}\text { Technical } \\
\text { maximum }\end{array}$ & $\begin{array}{l}\text { Measuring, reporting and verifying emissions is a } \\
\text { fundamental pre-requisite for effective, data-driven } \\
\text { policy. }\end{array}$ \\
\hline & & $\begin{array}{l}\text { Climate change } \\
\text { policy }\end{array}$ & $\begin{array}{l}\text { Climate Policy score (from the } \\
\text { Climate Change Performance } \\
\text { Index) }\end{array}$ & $\begin{array}{l}\text { eb_po } \\
\text { I_cpol }\end{array}$ & $\begin{array}{l}\text { Score 0- } \\
20\end{array}$ & $\begin{array}{l}\text { Burck et al. } \\
(2020)\end{array}$ & $\begin{array}{l}\text { https://ccpi.or } \\
\text { g/download/th } \\
\text { e-climate- } \\
\text { change- } \\
\text { performance- } \\
\text { index-2021/ }\end{array}$ & 2020 & $\begin{array}{l}23(7 \\
\text { imput- } \\
\text { ed) }\end{array}$ & 0 & 20 & $\begin{array}{c}\text { Existing } \\
\text { indicator/ind } \\
\text { ex scoring } \\
\text { range }\end{array}$ & $\begin{array}{c}\text { Existing } \\
\text { indicator/ind } \\
\text { ex scoring } \\
\text { range }\end{array}$ & $\begin{array}{l}\text { High policy ambition is necessary for guiding } \\
\text { investments and markets and providing direction for } \\
\text { implementation. Evaluating the ambition of countries' } \\
\text { climate change policies inevitably requires the use of } \\
\text { qualitative and subjective measures. }\end{array}$ \\
\hline
\end{tabular}

\begin{tabular}{|c|c|c|c|c|c|c|c|c|c|c|c|c|c|c|}
\hline 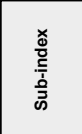 & 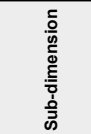 & 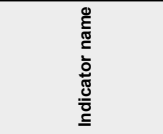 & 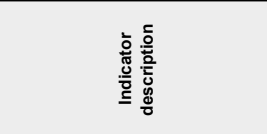 & 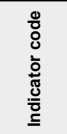 & $\stackrel{n}{5}$ & 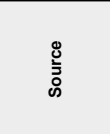 & $\stackrel{\vec{\alpha}}{د}$ & $\frac{\pi}{\frac{\pi}{\pi}}$ & 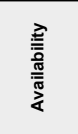 & $\dot{c}$ & 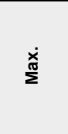 & 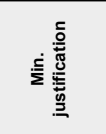 & 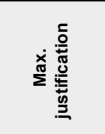 & 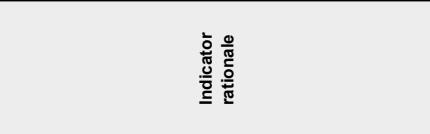 \\
\hline \multirow[t]{6}{*}{$\begin{array}{l}\text { EN- } \\
\text { ABLERS }\end{array}$} & \multirow{6}{*}{$\begin{array}{l}\text { Technol- } \\
\text { ogy, } \\
\text { knowl- } \\
\text { edge and } \\
\text { innovati } \\
\text { on }\end{array}$} & $\begin{array}{l}\text { Research and } \\
\text { development } \\
\text { expenditure }\end{array}$ & $\begin{array}{l}\text { Research and development } \\
\text { expenditure }\end{array}$ & $\begin{array}{l}\text { eb_tki } \\
\text { _rd }\end{array}$ & $\begin{array}{l}\text { \% of } \\
\text { GDP }\end{array}$ & $\begin{array}{l}\text { UNESCO } \\
\text { Institute for } \\
\text { Statistics } \\
(2021)\end{array}$ & $\begin{array}{l}\text { https://unstats } \\
\text {.un.org/sdgs/i } \\
\text { ndicators/data } \\
\text { base/ }\end{array}$ & $\begin{array}{l}2013- \\
2019 \\
\text { (latest) }\end{array}$ & $\begin{array}{c}29(1 \\
\text { imput- } \\
\text { ed })\end{array}$ & 0.05 & 3.65 & $\begin{array}{l}\text { Average of } \\
\text { bottom-3 } \\
\text { performers }\end{array}$ & $\begin{array}{l}\text { Average of } \\
\text { top-3 } \\
\text { performers }\end{array}$ & $\begin{array}{l}\text { R\&D expenditure is as a proxy for measuring public } \\
\text { finance inputs into creating knowledge and fostering } \\
\text { innovation around technology and other solutions that } \\
\text { support circular carbon economies. }\end{array}$ \\
\hline & & $\begin{array}{l}\text { Clean energy } \\
\text { technology patents }\end{array}$ & $\begin{array}{l}\text { WIPO patent applications/capita } \\
\text { (fuel cells, geothermal, solar and } \\
\text { wind energy), sum of } 5 \text { latest } \\
\text { years }\end{array}$ & $\begin{array}{l}\text { eb_tki } \\
\text { _pate }\end{array}$ & $\begin{array}{l}\text { Per } \\
1,000,00 \\
0 \\
\text { populatio }\end{array}$ & $\begin{array}{l}\text { WIPO } \\
(2021)\end{array}$ & $\begin{array}{l}\text { Data received } \\
\text { from WIPO }\end{array}$ & $\begin{array}{l}2016- \\
2020\end{array}$ & $\begin{array}{c}28(2 \\
\text { imput- } \\
\text { ed as } 0)\end{array}$ & 0.02 & 22.19 & $\begin{array}{l}\text { Average of } \\
\text { bottom-3 } \\
\text { performers }\end{array}$ & $\begin{array}{l}\text { Average of } \\
\text { top-3 } \\
\text { performers }\end{array}$ & $\begin{array}{l}\text { Clean energy technology patent applications measure } \\
\text { the knowledge and innovation outputs around technology } \\
\text { and other solutions that support the circularity of carbon } \\
\text { in the economy. }\end{array}$ \\
\hline & & $\begin{array}{l}\text { Academic research } \\
\text { intensity }\end{array}$ & Nature Index, 'share' & $\begin{array}{l}\text { eb_tki } \\
\text { enind } \\
\text { ex }\end{array}$ & $\begin{array}{l}\text { Share } / 1,0 \\
00,000 \\
\text { populatio } \\
\mathrm{n}\end{array}$ & $\begin{array}{l}\text { Springer } \\
\text { Nature } \\
(2021)\end{array}$ & $\begin{array}{l}\text { hitps://mww.na } \\
\text { tureindex.com } \\
\text { /country- } \\
\text { outputs/gener } \\
\text { ate//ll/global/ } \\
\text { All/score }\end{array}$ & $\begin{array}{l}\text { April } \\
2021\end{array}$ & 30 & 0.02 & 59.51 & $\begin{array}{l}\text { Average of } \\
\text { bottom-3 } \\
\text { performers }\end{array}$ & $\begin{array}{l}\text { Average of } \\
\text { top-3 } \\
\text { performers }\end{array}$ & $\begin{array}{l}\text { Academic research is a proxy for the knowledge } \\
\text { creation and dissemination activities that contribute to } \\
\text { the development and wide application of CCE-related } \\
\text { technologies. Academic research forms the basis for } \\
\text { most technological innovations, and also spreads } \\
\text { globally, benefiting other countries. }\end{array}$ \\
\hline & & $\begin{array}{l}\text { University and } \\
\text { industry technical } \\
\text { collaboration }\end{array}$ & $\begin{array}{l}\text { University/industry research } \\
\text { collaboration }\end{array}$ & $\begin{array}{l}\text { eb_tki } \\
\text {-unvin } \\
\text { dcol }\end{array}$ & $\begin{array}{l}\text { Score 0- } \\
100\end{array}$ & $\begin{array}{l}\text { TCdata360/ } \\
\text { World Bank } \\
\text { (2021) }\end{array}$ & $\begin{array}{l}\text { https://tcdata3 } \\
\text { 60.worldbank. } \\
\text { org/indicators/ } \\
\text { h4247b4d7 }\end{array}$ & $\begin{array}{l}2015- \\
2020 \\
\text { (latest) }\end{array}$ & 30 & 0 & 100 & $\begin{array}{l}\text { Existing } \\
\text { indicator/ind } \\
\text { ex scoring } \\
\text { range }\end{array}$ & $\begin{array}{c}\text { Existing } \\
\text { indicator/ind } \\
\text { ex scoring } \\
\text { range }\end{array}$ & $\begin{array}{l}\text { This indicator measures the extent of university-industry } \\
\text { collaboration, which can generate innovative solutions to } \\
\text { complex problems, such as industrial adaptation to } \\
\text { global energy transitions. It is also key for incubating } \\
\text { talent and innovation and the commercial mainstreaming } \\
\text { of new technologies. }\end{array}$ \\
\hline & & $\begin{array}{l}\text { Medium and high- } \\
\text { tech industry's } \\
\text { contribution to the } \\
\text { economy }\end{array}$ & $\begin{array}{l}\text { Medium and high-tech industry } \\
\text { value added (of total } \\
\text { manufacturing value added) }\end{array}$ & $\begin{array}{l}\text { eb_tki } \\
\text { iva }\end{array}$ & $\%$ & $\begin{array}{l}\text { UNIDO } \\
(2021)\end{array}$ & $\begin{array}{l}\text { https://data.w } \\
\text { orldbank.org/i } \\
\text { ndicator/NV. } \\
\text { MNF.TECH.Z } \\
\text { S.UN }\end{array}$ & 2018 & 30 & 5.45 & 60.70 & $\begin{array}{l}\text { Average of } \\
\text { bottom-3 } \\
\text { performers }\end{array}$ & $\begin{array}{l}\text { Average of } \\
\text { top-3 } \\
\text { performers }\end{array}$ & $\begin{array}{l}\text { Industrial development entails a structural transition from } \\
\text { resource-based and low technology activities to medium } \\
\text { and high-tech industry activities. A highly complex } \\
\text { production structure offers better opportunities for skills } \\
\text { development and technological innovation. }\end{array}$ \\
\hline & & $\begin{array}{l}\text { International high- } \\
\text { technology } \\
\text { interaction }\end{array}$ & $\begin{array}{l}\text { High-technology trade (export and } \\
\text { import)/total trade after exluding re- } \\
\text { imports/exports, combined }\end{array}$ & $\begin{array}{l}\text { eb_tki } \\
- \text { htec } \\
\text { htrade }\end{array}$ & $\begin{array}{l}\%, \text { sum } \\
\text { of } \\
\text { exports } \\
\text { and } \\
\text { imports } \\
\text { share }\end{array}$ & $\begin{array}{l}\text { TCdata360/ } \\
\text { World Bank } \\
(2021) / \\
\text { Cornell, } \\
\text { INSEAD and } \\
\text { WIPO } \\
(2020)\end{array}$ & $\begin{array}{l}\text { https://tcdata3 } \\
\text { 60.worldbank. } \\
\text { org/indicators/ } \\
68479 \text { bdf }\end{array}$ & $\begin{array}{l}2018- \\
2020 \\
\text { (latest) }\end{array}$ & $\begin{array}{l}28(2 \\
\text { imput- } \\
\text { ed) }\end{array}$ & 5.0 & 41.8 & $\begin{array}{l}\text { Average of } \\
\text { bottom-3 } \\
\text { performers }\end{array}$ & $\begin{array}{l}\text { Average of } \\
\text { top-3 } \\
\text { performers }\end{array}$ & $\begin{array}{l}\text { High-technology interaction with the rest of the world is a } \\
\text { proxy for technology diffusion and absorption capacity } \\
\text { for a country. Adaptation to the global energy transition } \\
\text { requires a significant change in industries' current } \\
\text { technological infrastructures, which in turn requires } \\
\text { active exchanges of technology and innovation globally. }\end{array}$ \\
\hline
\end{tabular}




\begin{tabular}{|c|c|c|c|c|c|c|c|c|c|c|c|c|c|c|}
\hline 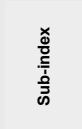 & 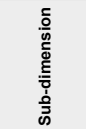 & 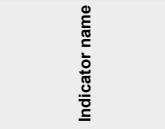 & 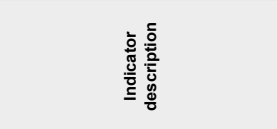 & 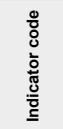 & $\stackrel{\frac{0}{5}}{5}$ & 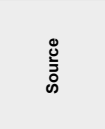 & $\overrightarrow{\underline{p}}$ & $\frac{\substack{\frac{\pi}{5} \\
\frac{\pi}{0}}}{\frac{0}{0}}$ & 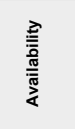 & $\dot{\Sigma}$ & $\stackrel{\substack{\infty \\
m}}{\Sigma}$ & 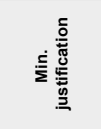 & 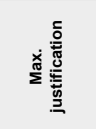 & 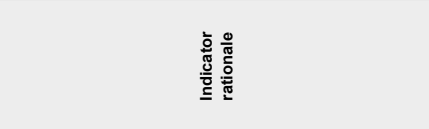 \\
\hline \multirow[t]{5}{*}{$\begin{array}{l}\text { EN- } \\
\text { ABLERS }\end{array}$} & \multirow[t]{5}{*}{$\begin{array}{l}\text { Finance } \\
\text { and } \\
\text { investme } \\
\text { nt }\end{array}$} & $\begin{array}{l}\text { Circular carbon } \\
\text { economy } \\
\text { investments }\end{array}$ & $\begin{array}{l}\text { Investments in renewable energy, } \\
\text { hydrogen, CCS, energy storage, } \\
\text { electrified heat and electrified } \\
\text { transport, sum of } 3 \text { latest years }\end{array}$ & $\begin{array}{l}\text { eb_fin } \\
\text { inv }\end{array}$ & $\begin{array}{l}\text { bn current } \\
\text { US\$/GDP } \\
2019, \text { bn } \\
\text { current } \\
\text { PPP US\$ }\end{array}$ & $\begin{array}{l}\text { Bloomberg } \\
\text { (2021) }\end{array}$ & $\begin{array}{l}\text { Data received } \\
\text { from } \\
\text { BloombergNE } \\
\text { F }\end{array}$ & $\begin{array}{l}2018- \\
2020 \\
\text { (total) }\end{array}$ & 30 & 0.000 & 0.036 & $\begin{array}{l}\text { Average of } \\
\text { bottom-3 } \\
\text { performers }\end{array}$ & $\begin{array}{l}\text { Average of } \\
\text { top-3 } \\
\text { performers }\end{array}$ & $\begin{array}{l}\text { This indicator captures financing of projects related to key } \\
\text { circular carbon economy activities financed from both } \\
\text { private and public resources. }\end{array}$ \\
\hline & & $\begin{array}{l}\text { Access to } \\
\text { sustainable finance }\end{array}$ & $\begin{array}{l}\text { Sustainable (green, social and } \\
\text { sustainability-linked) debt (bonds } \\
\text { and loans) issued per country of } \\
\text { domicile, } 5 \text { latest years) }\end{array}$ & $\begin{array}{l}\text { eb_fin } \\
\text { s-sdeb }\end{array}$ & $\begin{array}{l}\text { USD/GDP } \\
2019 \\
\text { current } \\
\text { PPP US\$ }\end{array}$ & $\begin{array}{l}\text { Bloomberg } \\
\text { (2021) }\end{array}$ & $\begin{array}{l}\text { https://www.bn } \\
\text { ef.com/ }\end{array}$ & $\begin{array}{l}\text { Sep } \\
2019- \\
\text { Sep } \\
2021 \\
\text { (total) }\end{array}$ & $\begin{array}{l}24(6 \\
\text { imputed } \\
\text { as zero) }\end{array}$ & 0.000 & 0.070 & $\begin{array}{l}\text { Average of } \\
\text { bottom-3 } \\
\text { performers }\end{array}$ & $\begin{array}{l}\text { Average of } \\
\text { top-3 } \\
\text { performers }\end{array}$ & $\begin{array}{l}\text { Leveraging the multi-trillion US\$ investments required for } \\
\text { circular carbon economy transitions is far beyond the } \\
\text { capacity of public resources. Involvement of private } \\
\text { finance, and enabling access to sustainable finance } \\
\text { instruments, is instrumental to bridging this gap. }\end{array}$ \\
\hline & & Access to finance & $\begin{array}{l}\text { Average (1) domestic credit to } \\
\text { private sector, \% of GDP, (2) stock } \\
\text { market capitalization, \% of GDP, }\end{array}$ & $\begin{array}{l}\text { eb_fin } \\
\text { accto } \\
\text { fin }\end{array}$ & $\begin{array}{l}\% \\
\text { (average) }\end{array}$ & $\begin{array}{l}\text { World Bank } \\
\text { (2021) }\end{array}$ & $\begin{array}{l}\text { https://databan } \\
\text { k.worldbank.or } \\
\text { g/source/world- }\end{array}$ & $\begin{array}{l}2017- \\
2019 / \\
2017-\end{array}$ & $\begin{array}{l}28(2 \\
\text { imp.), } \\
25(5\end{array}$ & $\begin{array}{l}12.04 \\
6.987 \\
0.230 \\
\end{array}$ & $\begin{array}{l}181.84 \\
198.89 \\
4.821\end{array}$ & $\begin{array}{l}\text { Average of } \\
\text { bottom-3 } \\
\text { performers }\end{array}$ & $\begin{array}{l}\text { Average of } \\
\text { top-3 } \\
\text { performers }\end{array}$ & $\begin{array}{l}\text { The vailability of traditional financial instruments also } \\
\text { contributes to circular carbon economy transitions, } \\
\text { especially in the case of small-scale sustainability projects }\end{array}$ \\
\hline & & $\begin{array}{l}\text { International financial } \\
\text { connectedness }\end{array}$ & $\begin{array}{l}\text { I Sum of (1) foreign direct investment } \\
\text { net inflows by foreigners, \% of GDP, } \\
\text { and (2) foreign direct net outflows by } \\
\text { residents, \% of GDP }\end{array}$ & eb_fin & $\begin{array}{l}\% \\
\text { (average) }\end{array}$ & $\begin{array}{l}\text { World Bank } \\
\text { (2021)/ IMF } \\
(2021)\end{array}$ & $\begin{array}{l}\text { https://databan } \\
\text { k.worldbank.or } \\
\text { g/source/world- } \\
\text { development- } \\
\text { indicators/\# }\end{array}$ & $\begin{array}{l}2017- \\
2019 \\
\text { (averag } \\
\text { e) }\end{array}$ & 30 & 0 & 6.89 & $\begin{array}{c}\text { Technical } \\
\text { limit }\end{array}$ & $\begin{array}{l}\text { Average of } \\
\text { top-3 } \\
\text { performers }\end{array}$ & $\begin{array}{l}\text { International financial connectedness is critical to ensure } \\
\text { countries' access to global capital oppurtunities for } \\
\text { financing both domestic and foreign circular carbon } \\
\text { economy-related projects and activities. While internal } \\
\text { flows support domestic transition, outward flows help other } \\
\text { countries progress toward this aim. }\end{array}$ \\
\hline & & Carbon pricing & $\begin{array}{l}\text { Emissions trading scheme or carbon } \\
\text { tax implemented (national level } 1, \\
\text { subnational level } 0.75), \text { scheduled } \\
(0.5) \text { or under consideration }(0.25)\end{array}$ & $\begin{array}{l}\text { eb_fin } \\
\text { cp }\end{array}$ & Score 0-1 & $\begin{array}{l}\text { World Bank } \\
\text { (2021) }\end{array}$ & $\begin{array}{l}\text { https://carbonp } \\
\text { ricingdashboar } \\
\text { d.worldbank.or } \\
\text { g/ }\end{array}$ & 2021 & 30 & 0 & 1 & $\begin{array}{l}\text { Average of } \\
\text { bottom-3 } \\
\text { performers }\end{array}$ & $\begin{array}{c}\text { Average of } \\
\text { top-3 } \\
\text { performers }\end{array}$ & $\begin{array}{l}\text { Pricing or valuing carbon is essential for enabling circular } \\
\text { carbon economies through market signals and economic } \\
\text { (dis)incentives. }\end{array}$ \\
\hline
\end{tabular}

\begin{tabular}{|c|c|c|c|c|c|c|c|c|c|c|c|c|c|c|}
\hline 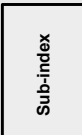 & 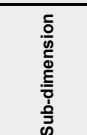 & 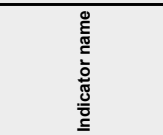 & 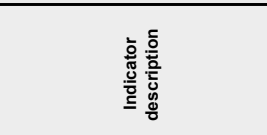 & 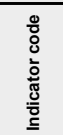 & $\stackrel{\frac{n}{2}}{5}$ & ֻँ & $\stackrel{\vec{q}}{J}$ & 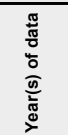 & 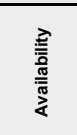 & $\dot{\Sigma}$ & 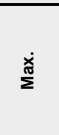 & 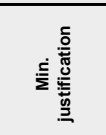 & 我 & 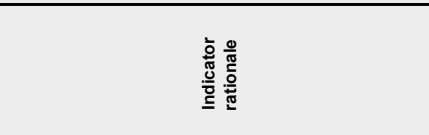 \\
\hline \multirow[t]{5}{*}{\begin{tabular}{|l|} 
EN- \\
ABLERS
\end{tabular}} & \multirow[t]{5}{*}{\begin{tabular}{l}
\multicolumn{1}{c}{ ( } \\
Busi- \\
ness \\
environ- \\
ment and \\
energy \\
security
\end{tabular}} & $\begin{array}{l}\text { Regulations } \\
\text { supporting business } \\
\text { activity }\end{array}$ & Ease of Doing Business score & $\begin{array}{l}\text { eb_be } \\
\text { i_eob }\end{array}$ & $\begin{array}{l}\text { Score 0- } \\
100\end{array}$ & $\begin{array}{l}\text { World Bank } \\
(2020)\end{array}$ & $\begin{array}{l}\text { https://mww.do } \\
\text { ingbusiness.o } \\
\mathrm{rg} / \mathrm{en} / \mathrm{rankings}\end{array}$ & 2019 & 30 & 44.87 & 83.83 & $\begin{array}{l}\text { Average of } \\
\text { bottom-3 } \\
\text { performers }\end{array}$ & $\begin{array}{l}\text { Average of } \\
\text { top-3 } \\
\text { performers }\end{array}$ & $\begin{array}{l}\text { This indicator is used as a proxy for regulatory } \\
\text { environments that support entrepreneurship and } \\
\text { business activity. Businesses are important for, among } \\
\text { other things, supporting the monetisation of } \mathrm{CO} 2 \text { and } \\
\text { the scaling up of various circular carbon economy- } \\
\text { related technologies. }\end{array}$ \\
\hline & & $\begin{array}{l}\text { Trade and transport } \\
\text { infrastructure }\end{array}$ & Logistics Performance Index & $\begin{array}{l}\text { eb_be } \\
\text { i_lpi }\end{array}$ & $\begin{array}{l}\text { Score 1- } \\
5\end{array}$ & $\begin{array}{l}\text { World Bank } \\
\text { (2018) }\end{array}$ & $\begin{array}{l}\text { https://lpi.worl } \\
\text { dbank.org/ }\end{array}$ & 2018 & 30 & 1.00 & 5.00 & $\begin{array}{l}\text { Existing } \\
\text { indicator/ind } \\
\text { ex scoring } \\
\text { range }\end{array}$ & $\begin{array}{c}\text { Existing } \\
\text { indicator/ind } \\
\text { ex scoring } \\
\text { range }\end{array}$ & $\begin{array}{l}\text { Strong and functioning trade and logistics chains can } \\
\text { lower trade costs and support country competitiveness. } \\
\text { Given countries' different natural endowments and } \\
\text { competitive advantages, trade can also help lower the } \\
\text { costs of managing } \mathrm{CO} 2 \text { emissions. }\end{array}$ \\
\hline & & $\begin{array}{l}\text { Renewable energy } \\
\text { investment and } \\
\text { deployment } \\
\text { opportunities }\end{array}$ & $\begin{array}{l}\text { Renewable Energy Country } \\
\text { Attractiveness Index }\end{array}$ & $\begin{array}{l}\text { eb_be } \\
\text { i_reca } \\
\text { i }\end{array}$ & $\begin{array}{l}\text { Score } 0- \\
100\end{array}$ & $\begin{array}{l}\text { EY (August } \\
2021 \text { ) }\end{array}$ & $\begin{array}{l}\text { https://nww.ey } \\
\text {.com/en_sa/r } \\
\text { ecai }\end{array}$ & 2021 & $\begin{array}{l}27(3 \\
\text { imput- } \\
\text { ed as } 0)\end{array}$ & 0 & 100 & $\begin{array}{l}\text { Existing } \\
\text { indicator/ind } \\
\text { ex scoring } \\
\text { range }\end{array}$ & $\begin{array}{l}\text { Existing } \\
\text { indicator/ind } \\
\text { ex scoring } \\
\text { range }\end{array}$ & $\begin{array}{l}\text { Renewable energy is a core circular carbon economy } \\
\text { activity. Further indicators to measure market } \\
\text { attractiveness in other areas can be included if/when } \\
\text { datasets become available. }\end{array}$ \\
\hline & & Energy security & $\begin{array}{l}\text { Share of fuel imports of total } \\
\text { imports of goods and services } \\
\text { (current US\$) }\end{array}$ & $\begin{array}{l}\text { eb_be } \\
\text { i_ens } \\
\text { ec }\end{array}$ & & $\begin{array}{l}\text { World Bank } \\
\text { (2021) }\end{array}$ & $\begin{array}{l}\text { https://data.w } \\
\text { orldbank.org/i } \\
\text { ndicator/TM.V } \\
\text { AL.FUEL.ZS. } \\
\text { UN }\end{array}$ & $\begin{array}{c}2014- \\
2019 \\
\text { (latest) }\end{array}$ & 30 & 0.005 & 0.222 & $\begin{array}{l}\text { Average of } \\
\text { bottom-3 } \\
\text { performers }\end{array}$ & $\begin{array}{l}\text { Average of } \\
\text { top-3 } \\
\text { performers }\end{array}$ & $\begin{array}{l}\text { Energy security in many countries is about fiscal } \\
\text { security. }\end{array}$ \\
\hline & & $\begin{array}{l}\text { Energy } \\
\text { infrastructure } \\
\text { stability }\end{array}$ & $\begin{array}{l}\text { Average of System average } \\
\text { interruption duration index (SAIDI) } \\
\text { and System average interruption } \\
\text { frequency index (SAIFI) }\end{array}$ & $\begin{array}{l}\text { eb_be } \\
\text { i_stab } \\
\text { ility }\end{array}$ & $\begin{array}{l}\text { Duration/ } \\
\text { frequen- } \\
\text { cy }\end{array}$ & $\begin{array}{l}\text { World Bank } \\
\text { GovData } \\
360(2021)\end{array}$ & $\begin{array}{l}\text { https://mww.do } \\
\text { ingbusiness.o } \\
\text { rg/en/doingbu } \\
\text { siness }\end{array}$ & 2020 & $\begin{array}{l}29(1 \\
\text { imput- } \\
\text { ed) }\end{array}$ & 20.34 & 0.04 & $\begin{array}{l}\text { Average of } \\
\text { bottom-3 } \\
\text { performers }\end{array}$ & $\begin{array}{l}\text { Average of } \\
\text { top-3 } \\
\text { performers } \\
\text { ( } 2 \text { outliers } \\
\text { excluded) }\end{array}$ & $\begin{array}{l}\text { Energy system stability is important for both enabling } \\
\text { circular carbon economy transitions and for creating } \\
\text { attractive environments for businesses and investments. }\end{array}$ \\
\hline
\end{tabular}




\begin{tabular}{|c|c|c|c|c|c|c|c|c|c|c|c|c|c|c|}
\hline 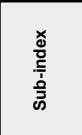 & 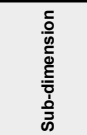 & 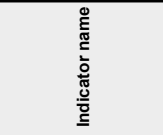 & 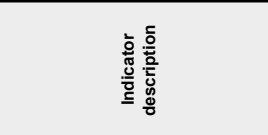 & 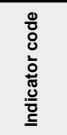 & $\stackrel{n}{\frac{n}{5}}$ & 巳ัٌ & $\overrightarrow{\underline{\mu}}$ & 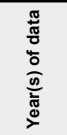 & 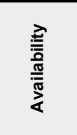 & $\dot{\Sigma}$ & 离 & 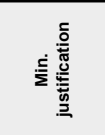 & 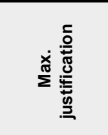 & 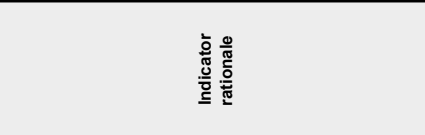 \\
\hline \multirow[t]{5}{*}{$\begin{array}{l}\text { EN- } \\
\text { ABLERS }\end{array}$} & \multirow[t]{5}{*}{$\begin{array}{l}\text { Busi- } \\
\text { ness } \\
\text { environ- } \\
\text { ment and } \\
\text { energy } \\
\text { security }\end{array}$} & $\begin{array}{l}\text { Regulations } \\
\text { supporting business } \\
\text { activity }\end{array}$ & Ease of Doing Business score & $\begin{array}{l}\text { eb_be s} \\
\text { i_eob }\end{array}$ & $\begin{array}{l}\text { Score 0- } \\
100\end{array}$ & $\begin{array}{l}\text { World Bank } \\
(2020)\end{array}$ & $\begin{array}{l}\text { https://mww.do } \\
\text { ingbusiness.o } \\
\text { rg/en/rankings }\end{array}$ & 2019 & 30 & 44.87 & 83.83 & $\begin{array}{l}\text { Average of } \\
\text { bottom-3 } \\
\text { performers }\end{array}$ & $\begin{array}{l}\text { Average of } \\
\text { top-3 } \\
\text { performers }\end{array}$ & $\begin{array}{l}\text { This indicator is used as a proxy for regulatory } \\
\text { environments that support entrepreneurship and } \\
\text { business activity. Businesses are important for, among } \\
\text { other things, supporting the monetisation of } \mathrm{CO} 2 \text { and } \\
\text { the scaling up of various circular carbon economy- } \\
\text { related technologies. }\end{array}$ \\
\hline & & $\begin{array}{l}\text { Trade and transport } \\
\text { infrastructure }\end{array}$ & Logistics Performance Index & $\begin{array}{l}\text { eb_be } \\
\text { i_lpi }\end{array}$ & $\begin{array}{l}\text { Score 1- } \\
5\end{array}$ & $\begin{array}{l}\text { World Bank } \\
(2018)\end{array}$ & $\begin{array}{l}\text { https://lpi.worl } \\
\text { dbank.org/ }\end{array}$ & 2018 & 30 & 1.00 & 5.00 & $\begin{array}{l}\text { Existing } \\
\text { indicator/ind } \\
\text { ex scoring } \\
\text { range }\end{array}$ & $\begin{array}{l}\text { Existing } \\
\text { indicator/ind } \\
\text { ex scoring } \\
\text { range }\end{array}$ & $\begin{array}{l}\text { Strong and functioning trade and logistics chains can } \\
\text { lower trade costs and support country competitiveness. } \\
\text { Given countries' different natural endowments and } \\
\text { competitive advantages, trade can also help lower the } \\
\text { costs of managing } \mathrm{CO} 2 \text { emissions. }\end{array}$ \\
\hline & & $\begin{array}{l}\text { Renewable energy } \\
\text { investment and } \\
\text { deployment } \\
\text { opportunities }\end{array}$ & $\begin{array}{l}\text { Renewable Energy Country } \\
\text { Attractiveness Index }\end{array}$ & $\begin{array}{l}\text { eb_be } \\
\text { i_reca } \\
i\end{array}$ & $\begin{array}{l}\text { Score } 0- \\
100\end{array}$ & $\begin{array}{l}\text { EY (August } \\
2021 \text { ) }\end{array}$ & $\begin{array}{l}\text { https://nww.ey } \\
\text { com/en_sa/r } \\
\text { ecai }\end{array}$ & 2021 & $\begin{array}{l}27(3 \\
\text { imput- } \\
\text { ed as } 0)\end{array}$ & 0 & 100 & $\begin{array}{l}\text { Existing } \\
\text { indicator/ind } \\
\text { ex scoring } \\
\text { range }\end{array}$ & $\begin{array}{l}\text { Existing } \\
\text { indicator/ind } \\
\text { ex scoring } \\
\text { range }\end{array}$ & $\begin{array}{l}\text { Renewable energy is a core circular carbon economy } \\
\text { activity. Further indicators to measure market } \\
\text { attractiveness in other areas can be included if/when } \\
\text { datasets become available. }\end{array}$ \\
\hline & & Energy security & $\begin{array}{l}\text { Share of fuel imports of total } \\
\text { imports of goods and services } \\
\text { (current US\$) }\end{array}$ & $\begin{array}{l}\text { eb_be } \\
\text { i_ens } \\
\text { ec }\end{array}$ & & $\begin{array}{l}\text { World Bank } \\
\text { (2021) }\end{array}$ & $\begin{array}{l}\text { https://data.w } \\
\text { orldbank.org/i } \\
\text { ndicator/TM.V } \\
\text { AL.FUEL.ZS. } \\
\text { UN }\end{array}$ & $\begin{array}{l}2014- \\
2019 \\
\text { (latest) }\end{array}$ & 30 & 0.005 & 0.222 & $\begin{array}{l}\text { Average of } \\
\text { bottom-3 } \\
\text { performers }\end{array}$ & $\begin{array}{l}\text { Average of } \\
\text { top-3 } \\
\text { performers }\end{array}$ & $\begin{array}{l}\text { Energy security in many countries is about fiscal } \\
\text { security. }\end{array}$ \\
\hline & & $\begin{array}{l}\text { Energy } \\
\text { infrastructure } \\
\text { stability }\end{array}$ & $\begin{array}{l}\text { Average of System average } \\
\text { interruption duration index (SAIDI) } \\
\text { and System average interruption } \\
\text { frequency index (SAIFI) }\end{array}$ & $\begin{array}{l}\text { eb_be } \\
\text { i_stab f } \\
\text { ility }\end{array}$ & $\begin{array}{l}\text { Duration/ } \\
\text { frequen- } \\
\text { cy }\end{array}$ & $\begin{array}{l}\text { World Bank } \\
\text { GovData } \\
360(2021)\end{array}$ & $\begin{array}{l}\text { https://mww.do } \\
\text { ingbusiness.o } \\
\text { rg/en/doingbu } \\
\text { siness }\end{array}$ & 2020 & $\begin{array}{l}29(1 \\
\text { imput- } \\
\text { ed) }\end{array}$ & 20.34 & 0.04 & $\begin{array}{l}\text { Average of } \\
\text { bottom-3 } \\
\text { performers }\end{array}$ & $\begin{array}{l}\text { Average of } \\
\text { top-3 } \\
\text { performers } \\
\text { ( } 2 \text { outliers } \\
\text { excluded) }\end{array}$ & $\begin{array}{l}\text { Energy system stability is important for both enabling } \\
\text { circular carbon economy transitions and for creating } \\
\text { attractive environments for businesses and investments. }\end{array}$ \\
\hline
\end{tabular}

\begin{tabular}{|c|c|c|c|c|c|c|c|c|c|c|c|c|c|c|}
\hline 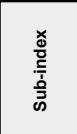 & 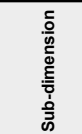 & 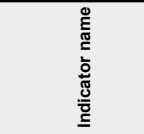 & 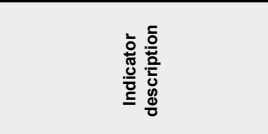 & 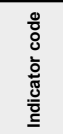 & $\stackrel{n}{5}$ & $\begin{array}{l}\text { ¿ } \\
\text { ஸें }\end{array}$ & $\stackrel{\vec{\alpha}}{丂}$ & 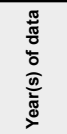 & 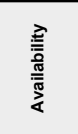 & $\dot{\Sigma}$ & $\stackrel{x}{\frac{x}{2}}$ & 突 & 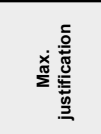 & 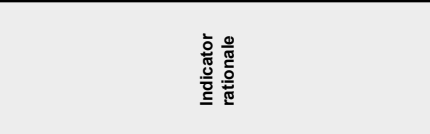 \\
\hline \multirow[t]{8}{*}{$\begin{array}{l}\text { EN- } \\
\text { ABLERS }\end{array}$} & \multirow[t]{8}{*}{$\begin{array}{l}\text { Socio- } \\
\text { eco- } \\
\text { nomic } \\
\text { context }\end{array}$} & $\begin{array}{l}\text { Economic } \\
\text { diversification }\end{array}$ & Economic Complexity Index & $\begin{array}{l}\text { eb_se } \\
\text { e_eci }\end{array}$ & $\begin{array}{l}\text { Deviation } \\
\text { from the } \\
\text { mean }\end{array}$ & $\begin{array}{l}\text { Harvard } \\
\text { Growth Lab } \\
(2021)\end{array}$ & $\begin{array}{l}\text { https://atlas.ci } \\
\text { d.harvard.edu } \\
\text { /rankings }\end{array}$ & 2019 & $\begin{array}{c}29(1 \\
\text { imputed } \\
)\end{array}$ & $\begin{array}{l}-1.43 \\
\end{array}$ & 2.20 & $\begin{array}{l}\text { Average of } \\
\text { bottom-3 } \\
\text { performers }\end{array}$ & $\begin{array}{l}\text { Average of } \\
\text { top-3 } \\
\text { performers }\end{array}$ & $\begin{array}{l}\text { Countries with higher levels of economic complexity } \\
\text { have been shown to be better placed to transition toward } \\
\text { more inclusive, sustainable, affordable and secure } \\
\text { energy systems. }\end{array}$ \\
\hline & & $\begin{array}{l}\text { Adjusted national } \\
\text { income }\end{array}$ & $\begin{array}{l}\text { Adjusted net national income per } \\
\text { capita }\end{array}$ & $\begin{array}{l}\text { eb_se } \\
\text { e_agn } \\
i\end{array}$ & $\begin{array}{l}\text { current } \\
\text { US\$ }\end{array}$ & $\begin{array}{l}\text { World Bank } \\
\text { (2021) }\end{array}$ & $\begin{array}{l}\text { https://data.w } \\
\text { orldbank.org/i } \\
\text { ndicator/NY.A } \\
\text { DJ.NNTY.PC. } \\
\text { CD }\end{array}$ & $\begin{array}{c}2019 \\
(3 \\
\text { countri } \\
\text { es } \\
2018)\end{array}$ & 30 & 1767 & 53845 & $\begin{array}{l}\text { Average of } \\
\text { bottom-3 } \\
\text { performers }\end{array}$ & $\begin{array}{l}\text { Average of } \\
\text { top-3 } \\
\text { performers }\end{array}$ & $\begin{array}{l}\text { Higher values on this adjusted wealth accounting } \\
\text { measure imply that the country is accumulating savings } \\
\text { that can be invested in circular carbon economy } \\
\text { transitions. }\end{array}$ \\
\hline & & Energy equity & $\begin{array}{l}\text { Energy Equity score (from the } \\
\text { Energy Trilemma Index) }\end{array}$ & $\begin{array}{l}\text { eb_se } \\
\text { e_equ } \\
\text { ity }\end{array}$ & $\begin{array}{l}\text { Score 0- } \\
100\end{array}$ & $\begin{array}{l}\text { World } \\
\text { Energy } \\
\text { Council } \\
(2020)\end{array}$ & $\begin{array}{l}\text { https://mww.w } \\
\text { orldenergy.or } \\
\text { g/publications/ } \\
\text { entry/world- } \\
\text { energy- } \\
\text { trilemma- } \\
\text { index-2020 }\end{array}$ & 2020 & 30 & 0 & 100 & $\begin{array}{l}\text { Existing } \\
\text { indicator/ind } \\
\text { ex scoring } \\
\text { range }\end{array}$ & $\begin{array}{l}\text { Existing } \\
\text { indicator/ind } \\
\text { ex scoring } \\
\text { range }\end{array}$ & $\begin{array}{l}\text { Equitable transitions to circular carbon economies are } \\
\text { at the core of the circular carbon economy's emphasis } \\
\text { on pragmatic, holistic and cost-effective approaches. }\end{array}$ \\
\hline & & Human capital & Human Capital Index & $\begin{array}{l}\text { eb_se } \\
\text { e_hci }\end{array}$ & $0-1$ & $\begin{array}{l}\text { World Bank } \\
(2020)\end{array}$ & $\begin{array}{l}\text { https://databa } \\
\text { nk.worldbank. } \\
\text { org/source/hu } \\
\text { man-capital- } \\
\text { index/ }\end{array}$ & 2020 & 30 & 0 & 1 & $\begin{array}{l}\text { Existing } \\
\text { indicator/ind } \\
\text { ex scoring } \\
\text { range }\end{array}$ & $\begin{array}{l}\text { Existing } \\
\text { indicator/ind } \\
\text { ex scoring } \\
\text { range }\end{array}$ & $\begin{array}{l}\text { Scaling up net-zero infrastructure and energy efficiency } \\
\text { requires a large, skilled workforce. }\end{array}$ \\
\hline & & Employment & $\begin{array}{l}\text { Employment to population ratio, } \\
15+, \text { total (modeled ILO estimate) }\end{array}$ & $\begin{array}{l}\text { eb_se } \\
\text { e_em } \\
\text { ploy }\end{array}$ & & $\begin{array}{l}\text { World Bank } \\
\text { (2021)/ ILO } \\
(2021)\end{array}$ & $\begin{array}{l}\text { https://data.w } \\
\text { orldbank.org/i } \\
\text { ndicator/SL.U } \\
\text { EM.TOTL.ZS }\end{array}$ & 2020 & 30 & 35.83 & 76.62 & $\begin{array}{l}\text { Average of } \\
\text { bottom-3 } \\
\text { performers }\end{array}$ & $\begin{array}{l}\text { Average of } \\
\text { top-3 } \\
\text { performers }\end{array}$ & $\begin{array}{l}\text { Transitions to circular carbon economies must also be } \\
\text { able to ensure employment and just transitions. }\end{array}$ \\
\hline & & $\begin{array}{l}\text { Quality of } \\
\text { governance }\end{array}$ & $\begin{array}{l}\text { Worldwide Governance Indicators } \\
\text { agrregate score }\end{array}$ & $\begin{array}{l}\text { eb_se } \\
\text { e_gov }\end{array}$ & $\begin{array}{l}\text { Average } \\
\text { score } \\
\text { (ca. }-2.5 \\
\text { to } 2.5 \text { ) }\end{array}$ & $\begin{array}{l}\text { NRGI, } \\
\text { Brookings, } \\
\text { World Bank } \\
(2020)\end{array}$ & $\begin{array}{l}\text { https://databa } \\
\text { nk.worldbank. } \\
\text { org/source/wo } \\
\text { rldwide- } \\
\text { governance- } \\
\text { indicators\# }\end{array}$ & 2019 & 30 & -2.5 & 2.5 & $\begin{array}{l}\text { Existing } \\
\text { indicator/ind } \\
\text { ex scoring } \\
\text { range }\end{array}$ & $\begin{array}{l}\text { Existing } \\
\text { indicator/ind } \\
\text { ex scoring } \\
\text { range }\end{array}$ & $\begin{array}{l}\text { In order to achieve any policy goal, countries need } \\
\text { strong legislative, political and judicial systems. }\end{array}$ \\
\hline & & $\begin{array}{l}\text { Environmental } \\
\text { health }\end{array}$ & $\begin{array}{l}\text { Mortality rate attributed to } \\
\text { household and ambient air } \\
\text { pollution, age-standardized }\end{array}$ & $\begin{array}{l}\text { eb_se } \\
\text { e_poll } \\
\text { ution }\end{array}$ & $\begin{array}{l}\text { Per } \\
100,000 \\
\text { populatio } \\
\mathrm{n}\end{array}$ & $\begin{array}{l}\text { World Bank } \\
(2021) / \\
\text { WHO } \\
(2021)\end{array}$ & $\begin{array}{l}\text { https://databa } \\
\text { nk.worldbank. } \\
\text { org/reports.as } \\
\text { px?source=3 } \\
\text { 11\&series=S } \\
\text { H.STA.AIRP. } \\
\text { P5 }\end{array}$ & 2016 & 30 & 203.4 & 8 & $\begin{array}{l}\text { Average of } \\
\text { bottom-3 } \\
\text { performers }\end{array}$ & $\begin{array}{l}\text { Average of } \\
\text { top-3 } \\
\text { performers }\end{array}$ & $\begin{array}{l}\text { Air pollution is one of the biggest environmental risks to } \\
\text { health, causing an estimated seven million premature } \\
\text { deaths annually. Lower levels of air pollution generally } \\
\text { indicate better management of hydrocarbons from a } \\
\text { health perspective. }\end{array}$ \\
\hline & & $\begin{array}{l}\text { Climate change } \\
\text { resilience }\end{array}$ & Global Climate Risk Index & $\begin{array}{l}\text { eb_se } \\
\text { e_cris } \\
\mathrm{k}\end{array}$ & $\begin{array}{l}\text { Score ca. } \\
1-118\end{array}$ & $\begin{array}{l}\text { Eckstein, } \\
\text { Künzel and } \\
\text { Schäfer } \\
\text { (2021) }\end{array}$ & $\begin{array}{l}\text { https://mww.ge } \\
\text { rmanwatch.or } \\
\text { g/en/cri }\end{array}$ & $\begin{array}{c}2019 \\
(1 \\
\text { country } \\
2018)\end{array}$ & 30 & 1 & 118 & $\begin{array}{l}\text { Existing } \\
\text { indicator/ind } \\
\text { ex scoring } \\
\text { range }\end{array}$ & $\begin{array}{l}\text { Existing } \\
\text { indicator/ind } \\
\text { ex scoring } \\
\text { range }\end{array}$ & $\begin{array}{l}\text { Building climate resilience ensures that vulnerable } \\
\text { populations are not left behind in transitions to circular } \\
\text { carbon economies. }\end{array}$ \\
\hline
\end{tabular}




\begin{tabular}{|c|c|c|c|c|c|c|c|c|c|c|c|c|c|c|}
\hline 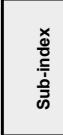 & 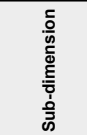 & 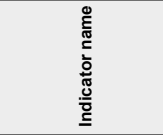 & 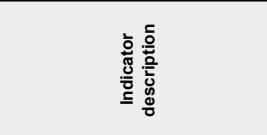 & 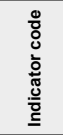 & $\stackrel{n}{5}$ & ֻั & $\overrightarrow{\underline{g}}$ & 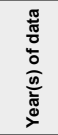 & 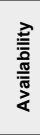 & $\dot{\Sigma}$ & $\stackrel{\frac{\dot{x}}{2}}{2}$ & 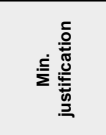 & 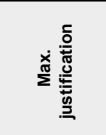 & 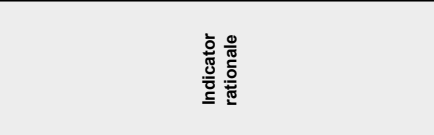 \\
\hline \multirow[t]{5}{*}{$\begin{array}{l}\text { OIL } \\
\text { PRO- } \\
\text { DUC- } \\
\text { ERS } \\
\text { LENS }\end{array}$} & \multirow[t]{5}{*}{ Enablers } & $\begin{array}{l}\text { Quality of resource } \\
\text { governance }\end{array}$ & $\begin{array}{l}\text { Value Realisation and Revenue } \\
\text { Management Scores for oil and } \\
\text { gas (from the Resource } \\
\text { Governance Index) }\end{array}$ & $\begin{array}{l}\text { eb_op } \\
\text { _rgi }\end{array}$ & $\begin{array}{l}\text { Score } 0- \\
100 \\
\text { (average } \\
\text { of the } \\
\text { two) }\end{array}$ & $\begin{array}{l}\text { Natural } \\
\text { Resource } \\
\text { Governance } \\
\text { Institute } \\
(2017)\end{array}$ & $\begin{array}{l}\text { https://resour } \\
\text { cegovernanc } \\
\text { eindex.org/ }\end{array}$ & 2017 & 19 & 0 & 100 & $\begin{array}{l}\text { Existing } \\
\text { indicator/ind } \\
\text { ex scoring } \\
\text { range }\end{array}$ & $\begin{array}{l}\text { Existing } \\
\text { indicator/ind } \\
\text { ex scoring } \\
\text { range }\end{array}$ & $\begin{array}{l}\text { The quality of governance around exploration, } \\
\text { production, environmental protection, revenue collection } \\
\text { and state-owned enterprises contribute to realizing } \\
\text { public value from a country's oil, gas and minerals } \\
\text { resources, and protect a country's local environment } \\
\text { and communities. }\end{array}$ \\
\hline & & $\begin{array}{l}\text { Environmental, } \\
\text { social and } \\
\text { governance risks }\end{array}$ & ESG Index & $\begin{array}{l}\text { eb_op } \\
\text { esgri } \\
\text { sk }\end{array}$ & $\begin{array}{l}\text { Score 0- } \\
100\end{array}$ & $\begin{array}{l}\text { Global Risk } \\
\text { Profile } \\
(2019)\end{array}$ & $\begin{array}{l}\text { hitps://risk- } \\
\text { indexes.com/ } \\
\text { esg-index/ }\end{array}$ & 2020 & 19 & 0 & 100 & $\begin{array}{l}\text { Existing } \\
\text { indicator/ind } \\
\text { ex scoring } \\
\text { range }\end{array}$ & $\begin{array}{l}\text { Existing } \\
\text { indicator/ind } \\
\text { ex scoring } \\
\text { range }\end{array}$ & $\begin{array}{l}\text { Stable, well-functioning and well governed social, } \\
\text { environmental and economic systems underpin the } \\
\text { generation of long-term sustainable returns for } \\
\text { businesses. }\end{array}$ \\
\hline & & $\begin{array}{l}\text { Company } \\
\text { sustainability } \\
\text { disclosures }\end{array}$ & $\begin{array}{l}\text { Number of sustainability } \\
\text { disclosure reports by multinational } \\
\text { and large energy, energy utility and } \\
\text { chemicals companies (ten latest } \\
\text { years) }\end{array}$ & $\begin{array}{l}\text { eb_op } \\
\text { sddi } \\
\text { sc }\end{array}$ & $\begin{array}{l}\text { No. of } \\
\text { reports } \\
\text { 2016- } \\
2020 / G D \\
\text { P 2019, } \\
100 \text { bn } \\
\text { current } \\
\text { PPP US\$ }\end{array}$ & GRI (2020) & $\begin{array}{l}\text { https://databa } \\
\text { se.globalrepor } \\
\text { ting.org/searc } \\
\mathrm{h} /\end{array}$ & $\begin{array}{l}2011- \\
2020 \\
\text { (sum) }\end{array}$ & 19 & 0 & 22.68 & $\begin{array}{l}\text { Average of } \\
\text { bottom-2 } \\
\text { performers }\end{array}$ & $\begin{array}{l}\text { Average of } \\
\text { top-2 } \\
\text { performers }\end{array}$ & $\begin{array}{l}\text { Transparent reporting of environment and sustainable } \\
\text { development-related business activities is used as a } \\
\text { proxy measure of how well major circular carbon } \\
\text { economy-relevant industries are positioning themselves } \\
\text { for a net-zero emissions future. }\end{array}$ \\
\hline & & $\begin{array}{l}\text { Carbon capture and } \\
\text { storage potential }\end{array}$ & $\begin{array}{l}\text { CCS Storage Indicator (from the } \\
\text { CCS Readiness Index) }\end{array}$ & $\begin{array}{l}\text { eb_op } \\
\text { gstora } \\
\text { ge }\end{array}$ & $\begin{array}{l}\text { Score 0- } \\
100\end{array}$ & $\begin{array}{l}\text { Global CCS } \\
\text { Institute } \\
(2021)\end{array}$ & $\begin{array}{l}\text { http:///mww.glo } \\
\text { balccsinstitute } \\
\text {.com/resourc } \\
\text { es/publication } \\
\text { s-reports- } \\
\text { research/glob } \\
\text { al-ccs- } \\
\text { institute-ccs- } \\
\text { readiness- } \\
\text { index/ }\end{array}$ & 2021 & 19 & 0 & 100 & $\begin{array}{l}\text { Existing } \\
\text { indicator/ind } \\
\text { ex scoring } \\
\text { range }\end{array}$ & $\begin{array}{l}\text { Existing } \\
\text { indicator/ind } \\
\text { ex scoring } \\
\text { range }\end{array}$ & $\begin{array}{l}\text { According to the Global CCS Institute, the availability of } \\
\text { storage resources is the ultimate prerequisite for carbon } \\
\text { capture and storage. }\end{array}$ \\
\hline & & $\begin{array}{l}\text { Government and } \\
\text { industry commitment } \\
\text { to net-zero } \\
\text { emissions }\end{array}$ & $\begin{array}{l}\text { National net zero target in law, } \\
\text { policy or under discusssion, and } \\
\text { participation in major industry net- } \\
\text { zero partnerships }\end{array}$ & $\begin{array}{l}\text { eb_op } \\
\text {-netz } \\
\text { ero }\end{array}$ & $\begin{array}{l}\text { Score 0- } \\
2.5\end{array}$ & $\begin{array}{l}\text { ECIU } \\
\text { (2021), } \\
\text { LeadlT } \\
\text { (2021), US } \\
\text { Department } \\
\text { of Energy } \\
(2021)\end{array}$ & $\begin{array}{l}\text { https://eciu.ne } \\
\text { t/netzerotrack } \\
\text { er/map }\end{array}$ & 2021 & 19 & 0 & 2.5 & $\begin{array}{l}\text { Average of } \\
\text { bottom-2 } \\
\text { performers }\end{array}$ & $\begin{array}{l}\text { Average of } \\
\text { top-2 } \\
\text { performers }\end{array}$ & $\begin{array}{l}\text { Net-zero emissions, or carbon circularity, is the ultimate } \\
\text { objective of the circular carbon economy. Government } \\
\text { and industry targets are a crucial signaling mechanism } \\
\text { for industry and investments in support of this objective. }\end{array}$ \\
\hline
\end{tabular}




\section{Appendix 2. Summary statistics for the 2021 CCE Index}

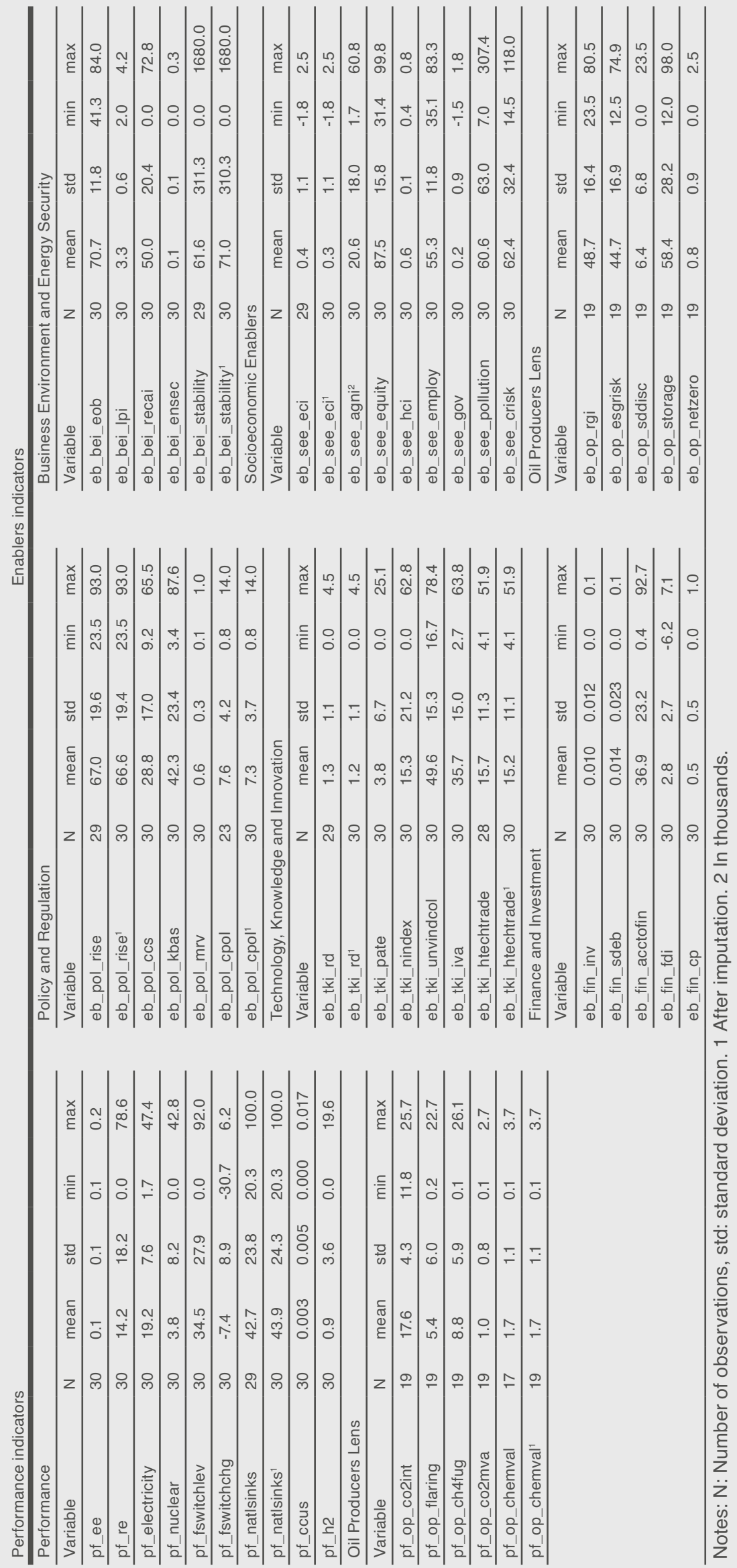




\section{Appendix 3. Indicator-specific imputations in the 2021 CCE Index}

\begin{tabular}{|c|c|c|c|c|c|c|c|c|c|c|c|c|c|c|c|c|c|c|c|c|c|c|c|c|c|c|c|c|c|}
\hline Sub-index & Dimension/lens & Indicator name & 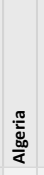 & 要 & 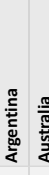 & 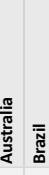 & 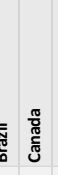 & 昘 & 壱 & 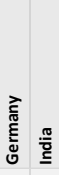 & 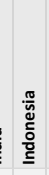 & 疋 & 胥 & 글 & 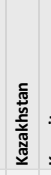 & & 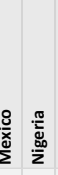 & 弯 & 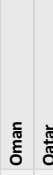 & 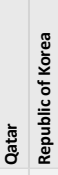 & 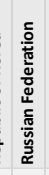 & 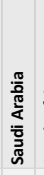 & & & 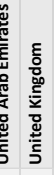 & 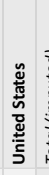 & 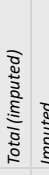 & 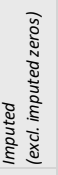 & $\begin{array}{l}\text { ठั. } \\
\text { อัँ } \\
\text { อे }\end{array}$ \\
\hline Performance & - & Nuclear energy & & & & ZI & & & & & & & & & & & & Zl & & & & & & ZI & & & 3 & 0 & $100 \%$ \\
\hline Performance & - & Natural sinks & & & & & & & & & & & & & & & & & & GI & & & & & & & 1 & 1 & $97 \%$ \\
\hline Performance & - & Carbon capture, utilization and storage & & $\mathrm{ZI}$ & & & & & & & & ZI & $\mathrm{ZI}$ & & $\mathrm{ZI}$ & & ZI & & $\mathrm{ZI}$ & & ZI & & & & & & 7 & 0 & $100 \%$ \\
\hline Performance & - & Clean hydrogen & $\mathrm{ZI}$ & $\mathrm{ZI} 2$ & $\mathrm{ZI}$ & & & & & & $\mathrm{ZI}$ & $\mathrm{ZI}$ & $\mathrm{ZI}$ & & & $\mathrm{ZI} \mathrm{ZI}$ & ZI ZI & & ZI z & $\mathrm{ZI}$ & ZI & & & ZI & & & 13 & 0 & $100 \%$ \\
\hline Performance & Oil Producers Lens & Value added of chemical industry & & GI & & & & & & & & & & & & & GI & & & & & & & & & & 2 & 2 & $89 \%$ \\
\hline Enablers & Policies and regulation & $\begin{array}{l}\text { Policy and regulatory support to energy } \\
\text { efficiency and renewables }\end{array}$ & & & & & & & & & & & GI & & & & & & & & & & & & & & 1 & 1 & $97 \%$ \\
\hline Enablers & Policies and regulation & $\begin{array}{l}\text { Carbon capture and storage policy, law and } \\
\text { regulation }\end{array}$ & & $\mathrm{SI}$ & SI & & & & & & & SI & SI & & $\mathrm{SI}$ & SI & SI & & & SI & & & & & & & 8 & 8 & $73 \%$ \\
\hline Enablers & Policies and regulation & Climate change policy & & GI & & & & & & & & & GI & & & GI & GI & & GI G & GI & & & & G & GI & & 7 & 7 & $77 \%$ \\
\hline Enablers & $\begin{array}{l}\text { Technology, knowledge } \\
\text { and innovation }\end{array}$ & $R \& D$ expenditure & & & & & & & & & & & & & & & GI & & & & & & & & & & 1 & 1 & $97 \%$ \\
\hline Enablers & $\begin{array}{l}\text { Technology, knowledge } \\
\text { and innovation }\end{array}$ & Clean energy technology patents & & $\mathrm{ZI}$ & & & & & & & & & & & & & ZI & & & & & & & & & & 2 & 0 & $100 \%$ \\
\hline Enablers & $\begin{array}{l}\text { Technology, knowledge } \\
\text { and innovation }\end{array}$ & International high-technology interaction & & GI & & & & & & & & & GI & & & & & & & & & & & & & & 2 & 2 & $93 \%$ \\
\hline Enablers & Finance and investment & Access to sustainable finance & $\mathrm{ZI}$ & $\mathrm{ZI}$ & & & & & & & & $\mathrm{ZI}$ & $\mathrm{ZI}$ & & & ZI & & & $\mathrm{ZI}$ & & & & & & & & 6 & 0 & $100 \%$ \\
\hline Enablers & Finance and investment & Access to finance* & GI & GI & & & GI & & & & & GI & GI GI & GI & & & & & & & & & & & GI & & 7 & 7 & $77 \%$ \\
\hline Enablers & $\begin{array}{l}\text { Business environments } \\
\text { and energy infrastructure }\end{array}$ & $\begin{array}{l}\text { Renewable energy investment and } \\
\text { deployment opportunities }\end{array}$ & & & & & & & & & & & $\mathrm{ZI}$ & & & & & & ZI Z & $\mathrm{ZI}$ & & & & & & & 3 & 0 & $100 \%$ \\
\hline Enablers & $\begin{array}{l}\text { Business environments } \\
\text { and energy infrastructure }\end{array}$ & Energy infrastructure stability & & & & & & & & & & & & & & & GI & & & & & & & & & & 1 & 1 & $97 \%$ \\
\hline \multirow[t]{5}{*}{ Enablers } & Socioeconomic enablers & Economic diversification & & & & & & & & & & & GI & & & & & & & & & & & & & & 1 & 1 & $97 \%$ \\
\hline & & Total imputed & m & $a$ & n- & $\rightarrow 0$ & C $\rightarrow$ & 0 & 0 & 00 & $\rightarrow$ & in & 우 & $\rightarrow 0$ & n & $A-4$ & $\rightarrow \infty$ & -1 & in $n$ & n 0 & N & $\circ$ & $\circ$ & $n-$ & -1 & 0 & & & \\
\hline & & Total imputed, excl. imputed zeros & -1 & in & $\rightarrow 0$ & $\circ 0$ & e & 0 & 0 & $\circ 0$ & 0 & $\sim$ & 07 & $\rightarrow 0$ & $\rightarrow$ & $n 0$ & 0 in & 0 & $\rightarrow$ & $m 0$ & 0 & $\circ$ & $\circ$ & 0 & -1 & 0 & & & \\
\hline & & Total indicators & f & F: & $\hat{m} \hat{m}$ & $\hat{m}$ f & f & f & m & $\hat{m} \hat{m}$ & $\hat{m}$ & $\hat{f}$ & $\hat{f} \hat{m}$ & $\hat{m} \hat{m}$ & f & fิ & ร & f & f & $\hat{f} \hat{m}$ & F & f & $\hat{m}$ & $\hat{m} f$ & f & f & & & \\
\hline & & Coverage & ळ & ळे ’े & 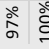 & 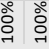 & కొ & ذ̊ำ & 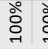 & 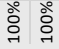 & ठ্ণ & ڤั & 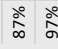 & 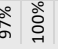 & 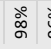 & 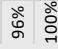 & ठั. & ذ̊ำ & ळे ఃे & ఫें ఫ్రి & ذి & 总 & & & ळे ळొ & ○ें & & & \\
\hline
\end{tabular}

Note: $\mathrm{ZI}$ = zero (score) imputed; GI = imputed as average of regional and income group; SI = imputed based on advice from original data source*

For "Access to finance," only one country (Iran) has imputed values for all three sub-components of the score. The other six countries have either one or two missing values. 


\section{Endnotes}

${ }_{1}^{1}$ For instance, following an early hit in 2020 from COVID-19, many emerging economies have experienced a major jump in initial public offerings on stock markets during the recovery phase.

${ }^{2}$ Exceptions were: R\&D expenditure (2013 for one country) and energy security (2014 for one country).

${ }^{3}$ In the application of PCA, we paid attention to the necessary statistics (two rules of thumb) to be satisfied, such as the eigenvalues associated with principal components need to be above one and the Kaiser-Meyer-Olkin (KMO) test needs to be above 0.5 (Jolliffe 2002). 


\section{References}

Al Saud, Noura, and Mashael Al Shalan. 2020. "The Circular Carbon Economy: A Global Blueprint for Carbon Circularity \& The Deployment of a Saudi Circular Carbon Economy Program." Discussion paper, April 2020. AEON Collective. https://static1.squarespace.com/ static/5d6d0c638a813e000101ddfc/t/5e9f1e7a9480a0 4441a28d7a/1587486336733A+Global+Blueprint+for+ Carbon+Circularity+\&+The+Deployment+of+a+Saudi+ Circular+Carbon+Economy+Program+\%7C+V.2.0..pdf

Bourcet, Clemence. 2020. "Empirical determinants of renewable energy deployment: A systematic literature review." Energy Economics vol 85(C). https://doi. org/10.1016/j.eneco.2019.104563

BP. 2020. "Statistical Review of World Energy. 69th edition." https://www.bp.com/content/dam/bp/businesssites/en/global/corporate/pdfs/energy-economics/ statistical-review/bp-stats-review-2020-full-report.pdf

Burck, Jan, Ursula Hagen, Niklas Höhne, Leonardo Nascimento, and Christoph Bals. 2020. "Climate Change Performance Index 2021." Germanwatch, CAN International and New Climate Institute. https://ccpi.org/ download/the-climate-change-performance-index-2021/

Consoli, Christopher P., lan Havercroft, and Lawrence Irlam. 2017. "Carbon capture and storage readiness index: comparative review of global progress towards wide-scale deployment." Energy Procedia 114: 73487355, https://doi.org/10.1016/j.egypro.2017.03.1585

Eckstein, David, Vera Künzel, and Laura Schäfer. 2021. "Global Climate Risk Index 2021." Germanwatch. https:// www.germanwatch.org/en/19777

Enerdata. 2021. "Global Energy and CO2 Database." Accessed September 27, 2021. https://www.enerdata.net/

Energy \& Climate Intelligence Unit. 2021. "Net Zero Tracker." Accessed September 12, 2021. https://eciu.net/ netzerotracker/map

Eurostat. 2014. Towards A Harmonised Methodology for Statistical Indicators. Part 1 - Indicator Typologies and Terminologies. 2014 edition. Luxembourg: Publication Office of the European Union. https://ec.europa.eu/ eurostat/web/products-manuals-and-guidelines/-/ ks-gq-14-011
-- - 2017a. Towards A Harmonised Methodology for Statistical Indicators. Part 2 - Communicating through Indicators. 2017 edition. Luxembourg: Publication Office of the European Union. https://ec.europa.eu/eurostat/ web/products-manuals-and-guidelines/-/ks-gq-17-001

- - - 2017b. Towards A Harmonised Methodology for Statistical Indicators. Part 3 - Relevance of Indicators for Policy Making. 2017 edition. Luxembourg: Publication Office of the European Union. https://ec.europa.eu/ eurostat/web/products-manuals-and-guidelines/-/ ks-gq-17-007

European Commission Joint Research Centre (JRC). 2004. "Composite Indicators - A Review." Presentation by Michaela Saisana at the Second Workshop on Composite Indicators of Country Performance, Paris, February 26-27, 2004. https://www.oecd.org/sti/ ind/29398640.pdf

EY. 2021. "Renewable Energy Country Attractiveness Index (RECAI)." Accessed September 14, 2021. https:// www.ey.com/en_sa/recai

G20 Climate Stewardship Working Group. 2020. "Managing Emissions in the Context of the Circular Carbon Economy Platform." Presidency Report. September 2020. https://www.g20.gov.sa/en/g20/ Documents/G20\%20CSWG\%20Outcome_Managing\%20 Emissions\%20in\%20the\%20Context\%20of\%20the\%20 CCE\%20Platform_Final_.pdf

G20 Energy Ministers. 2020. "G20 Energy Ministers Communique." September 27-28. http://www.g20. utoronto.ca/2020/G20SS_Energy_Ministers_Meeting_ Communique.pdf

Global CCS Institute. 2021. "Carbon Capture and Storage Index." https://www.globalccsinstitute. com/resources/publications-reports-research/ global-ccs-institute-ccs-readiness-index/

Global Reporting Initiative. 2020. "GRI Sustainability Disclosure Database." Accessed September 12, 2021. Last updated December 2020. https://database. globalreporting.org/search/

Global Risk Profile. 2019. "ESG Index." Accessed September 12, 2021. https://risk-indexes.com/esg-index/ 
Harvard Growth Lab. 2021. "Atlas of Economic Complexity: Country \& Product Complexity Rankings." Center for International Development at Harvard University. Accessed September 14, 2021. https://atlas. cid.harvard.edu/rankings

Institute of Energy Economics, Japan (IEEJ). 2021. "Energy Transition in the Post Corona World. Energy, Environment and Energy." IEEJ Outlook 2021, March. https://eneken.ieej.or.jp/en/whatsnew/436.html

International Energy Forum (IEF). 2020. "The Circular Carbon Economy." IEF Insight Brief, March. https://www. ief.org/programmes/circular-carbon-economy

Jing, Liang, Hassan M. El-Houjeiri, Jean-Christophe Monfort, Adam R. Brandt, Mohammad S. Masnadi, Deborah Gordon, and Joule A. Bergerson. 2020. "Carbon intensity of global crude oil refining and mitigation potential." Nature Climate Change 10 (2020): 526-532. https://doi.org/10.1038/s41558-020-0775-3

Jolliffe, I. T. 2002. Principal Component Analysis. 2nd Edition, Springer Series in Statistics. New York: Springer. https://doi.org/10.1007/b98835

KAPSARC. 2020. "CCE Guide: Overview. A guide to the circular carbon economy (CCE)." https://www.cceguide. org/guide/

Lafortune, Guillaume, Grayson Fuller, Jorge Moreno, Guido Schmidt-Traub, and Christian Kroll. 2018. "SDG Index and Dashboards: Detailed methodological paper." Bertelsmann Stiftung and the Sustainable Development Solutions Network (SDSN), September. https://raw. githubusercontent.com/sdsna/2018Globallndex/ master/2018GloballndexMethodology.pdf

Luomi, Mari, Fatih Yilmaz, and Thamir Alshehri. 2021a. "The Circular Carbon Economy Index 2021 - Results." KAPSARC Discussion Paper. https://doi.org/10.30573/ ks--2021-mp01

- - - 2021b. "Countries' Progress and Enablers for Circular Carbon Economies." KAPSARC Workshop Brief. September 2019. https://doi.org/10.30573/ KS--2021-WB04
Luomi, Mari, Fatih Yilmaz, Thamir Alshehri, and Nicholas Howarth. 2021. "The Circular Carbon Economy Index Methodological Approach and Conceptual Framework." KAPSARC Discussion Paper. May 2021. https://doi. org/10.30573/KS--2021-MP01

Mansouri, Noura Y., Alma Alhusseini, Noura T. Al-Saud, Mashael S. Alshalan, Maroua Benlahrech, Yoshikazu Kobayashi, Radia Sedaoui, Masakazu Toyoda, and Liubov Yaroshenko. 2020. "A Carbon Management System of Innovation: Towards a Circular Carbon Economy." Think-20 (T20) Saudi Arabia Policy Brief. https://www.g20-insights.org/policy_briefs/acarbonmanagement-system-of-innovation-towards-acircularcarbon-economy/

McDonough, William. 2016. "Carbon is not the enemy." Nature no. 539 (November 17): 349-351. https://doi. org/10.1038/539349a

Narula, K. and B.S. Reddy. 2015. "Three blind men and an elephant: The case of energy indices to measure energy security and energy sustainability." Energy vol. 80(C): 148-158. https://doi.org/10.1016/j. energy.2014.11.055

Natural Resource Governance Institute. 2017. "2017 Resource Governance Index." New York. https:// resourcegovernanceindex.org/publications-data/ global-report

Organisation for Economic Co-operation and Development (OECD). 2008. Handbook on Constructing Composite Indicators: Methodology and User Guide. OECD and European Commission's JRC. https://doi. org/10.1787/9789264043466-en

Saudi Aramco. 2020. "The circular carbon economy." Accessed February 20, 2020. https:// www.aramco.com/en/making-a-difference/planet/ the-circular-carbon-economy

Singh, Harsh Vijay, Roberto Bocca, Pedro Gomez, Steve Dahlke, and Morgan Bazilian. 2019. "The energy transitions index: An analytic framework for understanding the evolving global energy system." Energy Strategy Reviews 26 (2019). https://doi. org/10.1016/j.esr.2019.100382 
Springer Nature. 2021. "Nature Index: Country/territory outputs." Accessed September 20, 2021. https://www. natureindex.com/country-outputs/generate/All/global/All/ score

United Nations Economic Commission for Europe (UNECE). 2019. Guidelines on Producing Leading, Composite and Sentiment Indicators. https://doi. org/10.18356/3b565260-en

Weikmans, Romain, and Aarti Gupta. 2021. "Assessing state compliance with multilateral climate transparency requirements: 'Transparency Adherence Indices' and their research and policy implications." Climate Policy vol. 21, no. 5 (2021): 635-651. https://doi.org/10.1080/146930 62.2021.1895705

Wendling, Z. A., J.W. Emerson, A. de Sherbinin, D. C. Esty, et al. 2020. "2020 Environmental Performance Index." Yale Center for Environmental Law \& Policy. https://epi.yale.edu/
Williams, Eric. 2019. "Achieving Climate Goals by Closing the Loop in a Circular Carbon Economy." KAPSARC Instant Insight, November 9. https://www.kapsarc.org/ research/publications/achieving-climate-goals-by-closingthe-loop-in-a-circular-carbon-economy/

World Economic Forum (WEF). 2020. "Fostering Effective Energy Transition: 2020 Edition." Insight report. May 2020. http://www3.weforum.org/docs/WEF_Fostering_ Effective_Energy_Transition_2020_Edition.pdf

World Energy Council (WEC). 2020. "World Energy Trilemma Index 2020." https://www.worldenergy.org/ publications/entry/world-energy-trilemma-index-2020 


\section{Notes}

(20) 
Notes 


\section{Notes}

(20) 


\title{
About the Authors
}

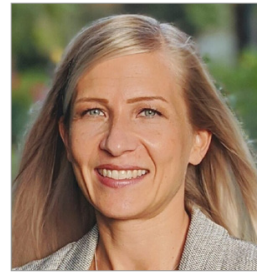

\author{
Mari Luomi
}

Mari is a policy-oriented social scientist who has been studying climate change, energy transitions and sustainable development policy in the Gulf and globally for close to 15 years. She has worked for other leading energy, sustainable development and foreign policy research institutions, including the Oxford Institute for Energy Studies, the International Institute for Sustainable Development (Earth Negotiations Bulletin), Georgetown University, the Finnish Institute of International Affairs, and the Emirates Diplomatic Academy.

Mari holds a master's degree in political science and international politics from the University of Helsinki and a Ph.D. in Middle Eastern Studies from Durham University. In addition to a broad research publications portfolio, she has substantial experience in executive training, presentations, policy advisory, and reporting services for multilateral environmental negotiations.

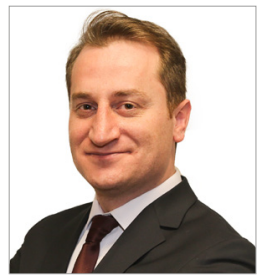

\section{Fatih Yilmaz}

Fatih is a senior research associate in the Energy Transitions and Electric Power program. His current research agenda aims to enhance our understanding of the financial and economic consequences of the global energy transition toward renewables, and to design effective policies to balance financial risks and growth prospects.

Before joining KAPSARC, Fatih worked as an economist at the Structural Economic Research Department of the Central Bank of the Republic of Turkey, where he was involved in research and designing policies for the real and financial sectors. He has worked as a consultant for the World Bank and spent a year as an assistant professor of economics at the ADA University. He has authored various academic and policy articles and helped to organize conferences and workshops. He holds a Ph.D. in economics from the University of Calgary. 


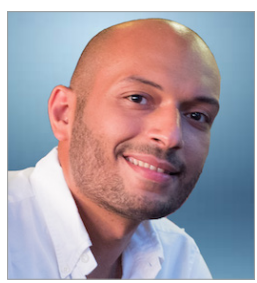

\section{Thamir Alshehri}

Thamir is a research associate in the Energy Transitions and Electric Power program. $\mathrm{He}$ is currently focused on creating data-driven tools to identify and evaluate different energy market scenarios, as well as using 'big data' technologies to better understand the impact of consumer behavior and the environment on energy consumption. Thamir is interested in using technologies to facilitate better energy public policy and energy economical systems.

Thamir also acts as an advisor to the broader energy ecosystem in Saudi Arabia, particularly in the areas of clean energy transitions, sustainability, and carbon emissions management. He is also a member of the Technology and Economic Assessment Panel, United Nations Environment Programme (UNEP).

He previously worked as a lecturer in Australia and has entrepreneurial and industrial experience working on award-winning projects such as the Burj Khalifah Building Management System.

\section{About the Project}

The Circular Carbon Economy (CCE) Index project seeks to expand and add rigor to the conceptual basis of the concept of the CCE, as well as its practical operationalization, by developing a robust quantitative framework to measure country performance and progress toward achieving CCEs. The resulting CCE Index is a composite indicator that measures various dimensions of the CCE in a national context across countries. Its main foci are current performance and enabling factors for future progress.

The project consists of various components, including a consultation paper published in June 2021, which provided a preliminary conceptual-methodological framework for the CCE Index and was used by the index team to support related expert and stakeholder consultations. The CCE Index also convened an International Technical Advisory Committee, with five initial members, to help improve the robustness of the index methodology.

This first edition of the CCE Index covers 30 major economies and oil-producing countries. It is being disseminated through various research outputs, including this methodology paper, a discussion paper presenting the 2021 CCE Index results, and an online platform, located at: https://cceindex.kapsarc.org.

The CCE Index has two main functions: first, it is intended to enable further discussions around ways to identify, measure and compare countries' strengths and weaknesses in terms of the CCE, and to help pinpoint areas where progress is already well underway and where further policy efforts are needed or could be beneficial. Second, the index promotes the further understanding of the CCE concept and the overall idea of adopting a holistic approach to managing emissions across energy systems and economies and achieving carbon circularity. The project also seeks to support discussions within Saudi Arabia, and other interested countries, on ways to measure and advance toward CCEs. 
INAPSARC

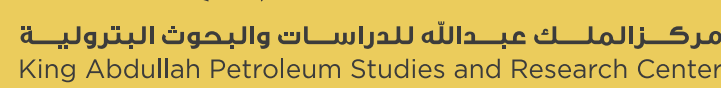

www.kapsarc.org 